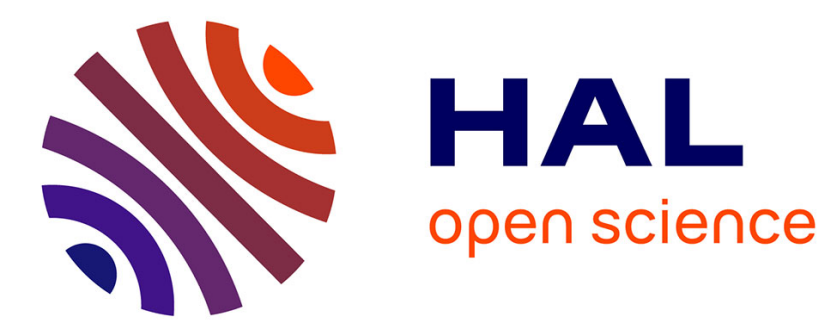

\title{
Inequality, poverty and the intra-household allocation of consumption in Senegal
}

Philippe de Vreyer, Sylvie Lambert

\section{To cite this version:}

Philippe de Vreyer, Sylvie Lambert. Inequality, poverty and the intra-household allocation of consumption in Senegal. 2019. halshs-02177745

\section{HAL Id: halshs-02177745 \\ https://shs.hal.science/halshs-02177745}

Preprint submitted on 9 Jul 2019

HAL is a multi-disciplinary open access archive for the deposit and dissemination of scientific research documents, whether they are published or not. The documents may come from teaching and research institutions in France or abroad, or from public or private research centers.
L'archive ouverte pluridisciplinaire HAL, est destinée au dépôt et à la diffusion de documents scientifiques de niveau recherche, publiés ou non, émanant des établissements d'enseignement et de recherche français ou étrangers, des laboratoires publics ou privés. 


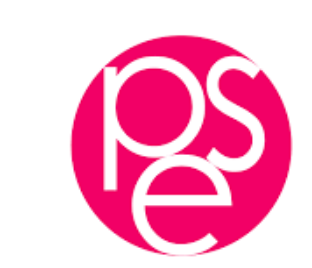

PARISSCHOOL OFECONOMICS
ECOLED'ECONOMIEDE PARIS

WORKING PAPER N 2019 - 33

Inequality, poverty and the intra-household allocation of consumption in Senegal

\author{
Philippe De Vreyer \\ Sylvie Lambert
}

JEL Codes: C81, D13, D31, 132, 012, 015

Keywords : Inequality, Poverty, Household sruveys, Intra-household allocation, Senegal 


\title{
INEQUALITY, POVERTY AND THE INTRA-HOUSEHOLD ALLOCATION OF CONSUMPTION IN SENEGAL
}

\author{
PHILIPPE DE VREYER \\ (Université Paris-Dauphine, PSL Research University, CNRS, IRD, LEDa, DIAL) \\ SYLVIE LAMBERT \\ (Paris School of Economics, INRA)
}

JUNE 2019

\begin{abstract}
:
Intra-household inequalities have long been a source of concern for policy design, but there is very little evidence. The current practice of ignoring inequality within households could lead to an underestimation of both overall inequality and poverty levels, as well as to the misclassification of some individuals as regards to their poverty status. Using a novel survey for Senegal in which consumption data were collected at a disaggregated level, this paper quantifies these various effects. In total, two opposing effects, one on mean and one on inequality, compensate each other in terms of the overall poverty rate, but individual poverty statuses are affected. Intra-household consumption inequalities accounts for $14 \%$ of inequality in Senegal. We uncover the fact that household structure and organization are key correlates of intra-household inequality and individual risk of poverty.
\end{abstract}

JEL: C81, D13, D31, I32, 012, 015

Keywords: Inequality, Poverty, Household surveys, Intra-household allocation, Senegal.

We thank IDRC (International Development Research Center), INRA-Paris, and CEPREMAP for funding data collection, UNICEF for supporting preliminary work, and the NOPOOR program of the European Union for research support. This work has also been supported by the French National Research Agency, through the program Investissements d'Avenir, ANR-10--LABX_93-0.1. We thank Momar B. Sylla, whose insights proved invaluable to gain a better understanding of the context. For comments and suggestions, we are especially indebted to Denis Cogneau, Martin Ravallion, Dominique van de Walle and Stephan Klasen. Three anonymous referees are gratefully acknowledged for constructive comments. We are also thankful to participants in the 2016 EUDN workshop and 2017 CSAE conference, and seminar at Nova, Lisboa. We thank Anne-Sophie Robilliard for providing us access to the ESPS database

Contact: Philippe De Vreyer: philippe.devreyer@dauphine.psl.eu; Sylvie Lambert: sylvie.lambert@psemail.eu 


\section{INTRODUCTION}

Inter-personal inequality in living standards within households is a largely uncharted territory. It is unlikely that individuals within the same household always have the same living standards as income and resources are not necessarily pooled, and members do not share in them equally. If this is the case, inequality levels might well be seriously underestimated. Further, this is a question of major policy relevance as unequal access to resources might push vulnerable household members to alarmingly low consumption levels. However, gauging the extent of intra-household inequality remains an empirical challenge, since adequate data are rarely at hand.

The purpose of this paper is to provide a measure and a description of intra-household inequality in the case of Senegal using a novel survey in which household consumption data were collected at a disaggregated level, evaluate how it alters our assessment of consumption distribution in the country and identify which categories of household members are most at risk to suffer from relative deprivation.

The distribution of consumption in West-African economies is often considered to be less unequal than in other parts of Africa and Latin America; the Gini indices are around 40\%, while they reach the range 50 to $60 \%$ in many Austral African or Latin American countries (see fig 2.9, chap. 2; World Bank 2005). Still, not only is income inequality fairly high (Beegle at al. 2016), but, as pointed out by Cogneau et al (2006), it is accompanied by low intergenerational social mobility, suggesting that inequality is weighing on individual life trajectories.

The above inequality assessment is based on standard consumption surveys, which collect information at the level of the household as a whole, often by interviewing its head. Individual consumption levels are derived from this aggregate measure. This might be a poor 
approximation of reality in the context of Senegal, where households extend far beyond the parents-children nucleus, and the chances for unequal distribution of resources among household members are particularly large. The household structure is in fact quite complex, due to polygamy, to the frequent presence of foster children (Beck et al 2015) and of extended family members.

Most of the empirical work attempting to exhibit intra-household inequalities concentrates on food consumption or health and education (see Haddad et al. 1997 for an excellent introduction to the early research on these topics). More recently, some works based on structural models of intra-household allocation of resources (collective household models, see Chiappori 1988) deliver estimates of consumption shares by type of household members for nuclear households (Dunbar et al. 2013). In general, these estimates cannot be confronted to the actual sharing of resources, as these data are rarely available. The only exceptions we know of are two recent papers, using Bangladeshi data and concentrating on food consumption (Bargain et al. 2018, Brown et al. 2019). The complex structure and budgetary organization of West-African households with separate spheres of spending suggest that the Pareto optimality assumption supporting those structural models is unlikely to be verified (see Baland and Ziparo 2018). Hence, this route might not be particularly promising in such context.

Recent attempts at describing intra-household resource allocation with non-monetary measures of poverty also exist. Klasen and Lahoti (2016) study inter-individual inequality in India using individual multidimensional poverty indices (MPI), compared with the distribution of a household-based MPI. They find that intra-household inequality accounts for $30 \%$ of total inequality. More relevant to our context, Brown, Ravallion and van de Walle (forthcoming) use nutritional status as a proxy for individual poverty and observe that in 
Africa, around one half of undernourished women and children are not found in the (asset-) poorest $40 \%$ of households.

In addition, we now have strong evidence that individuals within a household may not be equally vulnerable to shocks (Case, Paxson and Ableidinger 2004, Dercon and Krishnan 2000, De Vreyer and Nilsson 2019, Rose 1999).

Despite these efforts, since very few datasets permit researchers to measure individual consumption and thereby intra-household inequality, available estimates of poverty and inequality simply ignore this issue. Standard measures of poverty and inequality are calculated assuming that resources are shared equally within the household (with some normalization for size and demographic composition). From the conceptual standpoint alone, viewing poverty as essentially an individual state requires us to go beyond this approach. From the policy point of view, neglecting intra-household inequality is likely to introduce biases in the poverty and inequality measures. Less obvious is the fact that household-based consumption data collection could also lead to an underestimation of mean consumption, which might in turn bias poverty estimates upwards.

We conducted an unusual survey aimed at better understanding household structure and intrahousehold resource allocation in Senegal (Poverty and Family Structure survey, hereafter PSF, see De Vreyer et al. 2008). The consumption section of the survey has been designed to collect consumption expenditures at the level of small groups within the household, and involved the interview of several household members. ${ }^{1}$ The data can be used to construct a measure of consumption at the cell level, allowing a more precise assessment of individual consumption than permitted by traditional surveys.

\footnotetext{
1 The way these subgroups have been defined is described in detail in section 2.1.
} 
These data are very revealing on intra-household inequalities. In general, food expenditures appear equitably distributed as far as their actual inter-individual allocation is observable (Meals are mostly collectively taken from a single dish, see section 2.3). Differences emerge with respect to non-food expenditures. We evaluate intra-household inequalities to account for $14 \%$ of total inequalities in Senegal. This number is shown to be $42 \%$ of the maximum that could be reached given the very large share of common expenditures (including food) in this context. This might be an underestimation, given the difficulty to observe inequality in food consumption. The overall consumption inequality is much higher than what is commonly thought, with a Gini index estimated to reach $47.1 \%$, before we even factor in intra-household inequality. ${ }^{2}$ Further, holding account of the intra-household inequality we can observe leads to revise upward the overall level of consumption inequality, up to nearly $50 \%$ for the Gini coefficient.

We find poverty measures very comparable to those produced with a more standard household survey conducted only a few months earlier. On the one hand, the mode of data collection (more than one respondent per household in PSF) seems to allow for a more complete recording of consumption leading to a $15 \%$ higher level of average consumption. On the other hand, in this context, taking into account intra-household inequalities increases the share of individuals found below the poverty line. Remarkably, in the case of Senegal, these two differences compensate each other so that the overall evaluation of poverty level doesn't depend on the survey used. The poverty rate reaches about $43 \%$ at the time of our survey when using a basic needs poverty threshold. We further discuss how ignoring inter-

\footnotetext{
2 The Gini index published by the World Bank reaches 40.3\% in 2011 (World Development Indicators).
} 
personal inequality leads to flawed poverty diagnostics. We find that nearly $14 \%$ of non-poor households contain at least one poor cell. There are also non-poor cells in poor households.

We conduct a number of robustness checks. Worries that the inequality results could be in part driven by measurement errors are tackled with corrections of the inequality estimates as well as with simulation techniques. Qualitatively, all results stand for plausible levels of measurement errors. Further, poverty estimates are obviously dependent on the poverty line and we explore sensitivity to this choice. We also examine how results are affected by the equivalence scale used to weigh individuals within households.

The paper is organized as follows. In Section 2, we present the data collected, and examine the likely implications of observing consumption at an infra household level on estimated inequalities and poverty levels. In section 3, we describe intra-household inequality and its contribution to overall inter-individual inequality. Section 4 is dedicated to the revision of poverty assessments brought about by the prevalence of intra-household inequalities, and Section 5 presents some robustness checks. Section 6 concludes.

\section{The "POVERTY AND FAMILY STRUCTURE" SURVEY}

\subsection{THE SURVEY}

The PSF Survey was conducted in Senegal in 2006-2007. It results from the cooperation between the National Statistical Office of Senegal and a team of French researchers. ${ }^{3}$ It is a

\footnotetext{
${ }^{3}$ Momar B. Sylla and Matar Gueye of the Agence Nationale de la Statistique et de la Démographie of Sénégal (ANSD), as well as Philippe De Vreyer (University of Paris-Dauphine and IRD-DIAL), Sylvie Lambert (Paris School of EconomicsINRA), and Abla Safir (World Bank), all designed the survey. The data collection was conducted by the ANSD, thanks to the funding of the IDRC (International Development Research Center), INRA Paris, and CEPREMAP. The survey is described in detail in De Vreyer et al., 2008.
} 
nationally representative survey covering 1,800 households spread over 150 clusters drawn randomly from the census districts so as to insure a nationally representative sample. About 1,780 records can be exploited. Nevertheless, for the purpose of this paper, we exclude households with missing consumption information or incoherent records. ${ }^{4}$ We are left with a sample of 1762 households. Among them more than half live in rural areas, while $28 \%$ are in Dakar.

The survey collects the usual information on individual characteristics, as well as a detailed description of household structure, consumption, and budgetary arrangements.

\section{HOUSEHOLD STRUCTURE}

In the PSF survey, a household is defined as the set of co-residing individuals who recognize the authority of a given household head. Table 1 describes the main characteristics of Senegalese households. In the PSF sample they are large, with about eight members on average and a dependency ratio nearly equal to 50\%. Households are typically multigenerational and extended both horizontally and vertically, with $28.2 \%$ of members that are neither the head, nor one of his wives or children. ${ }^{5}$ Two thirds of households include such “extended” family members.

Polygamous unions are common, with $24.7 \%$ of married men and $38.7 \%$ of married women engaged in such unions. Most of these comprise a husband and two wives (only 20\% of polygamous unions have more than two wives). We find that $31 \%$ of polygamous men have

\footnotetext{
${ }^{4}$ Details are given in Appendix A.

5 Vertical extensions refer to the cases where the household includes more than 2 generations of members, i.e. presence of grand-parents or grand-children. Horizontal extensions subsume situations where several family members pertaining to the generation of the head cohabit. It could be for example married siblings of the head or of his wife.
} 
non-cohabiting wives. In this work, we ignore the consumption of non-co-residing spouses of the household head.

Field interviews conducted at the early stages of the PSF project showed that within Senegalese households, it is possible to distinguish sub-groups of household members that are at least partly autonomous, in particular with respect to their budget management. To best capture intra-household structure and resource allocation, the survey was designed to record this internal household organisation. Each household was divided into groups, called “cells”, whereby the head forms a cell with unaccompanied dependent members (a widowed parent, a child whose mother is not present in the household, an unmarried sibling when no parent coresides...); each wife of the head, her children, and any other dependents then form separate cells, as do any other adults with dependent (such as a married brother or a married son, for example). A similar approach had already been used to structure households in the 1988 Senegalese census (van de Walle and Gaye, 2006) and seemed very intuitive to enumerators who had to implement the survey. In the PSF sample, more than a third of households contain at least three cells (see Table 1 below). ${ }^{6}$ Households have on average 2.5 cells, but that uncovers a wide diversity of situation. In fact, nearly $18 \%$ of the households have only one cell, while 38\% have 3 cells or more. Nuclear households (composed of husband, wife and their unmarried children) account for about $40 \%$ of the households, while nearly $49 \%$ include some type of horizontal (siblings, but also uncles/aunts or nephews/nieces) or vertical extensions (parents, grand-parents, grand-children). The cohabitation of 3 generations or more is particularly frequent in rural areas, where it is the case for $44 \%$ of the households (vs $22 \%$ in Dakar). The remaining extended households include cousins or non-family members. Despite these frequent extensions, only in $15.8 \%$ of the households do we observe more than

\footnotetext{
${ }^{6}$ Half of the households with 3 cells or more are headed by a polygamous household head.
} 
one married man with at least one wife present in the household. About one fifth of the households are headed by a woman and two-thirds by someone without any formal schooling (either no education at all or only koranic educations).

When zooming to the cell level, $40 \%$ are headed by the household head (a man in nearly $80 \%$ of the cases), $35 \%$ by his spouse, and $11 \%$ by one of his children or a son or daughter-in-law. Cells other than that of the household head are in vast majority (81\%) headed by a woman. Nearly a third of the cells include at least two adults above the age of 21 (47\% if considering individuals over 15), while the number of children below 15 varies from 0 (for nearly $44 \%$ of the cells) to 8, with an average of 1.36. Nearly half of the cells are those of a mother and her children. Women also tend to have under their responsibility grand-children, younger unmarried siblings or nephews and nieces.

Table 1a: Household characteristics

\begin{tabular}{|c|c|c|c|c|}
\hline & $\mathrm{N}$ & mean & Min & $\max$ \\
\hline Household size & 1,762 & 8.09 & 1 & 44 \\
\hline number of cells & 1,762 & 2.49 & 1 & 12 \\
\hline single cell household & 1,762 & 17.70 & 0 & 100 \\
\hline hh with 3 cells or more & 1,762 & 37.82 & 0 & 100 \\
\hline hh with 2 couples of more & 1,762 & 15.76 & 0 & 100 \\
\hline nb of children 0 - 4 y.o. & 1,762 & 1.23 & 0 & 10 \\
\hline nb of children 5 - 14 y.o. & 1,762 & 2.15 & 0 & 13 \\
\hline nb of elderly over 66 y.o. & 1,762 & 0.30 & 0 & 4 \\
\hline nuclear household & 1,762 & 40.55 & 0 & 100 \\
\hline hh include vertical extensions & 1,762 & 35.12 & 0 & 100 \\
\hline hh includes horizontal extensions & 1,762 & 27.41 & 0 & 100 \\
\hline hh includes vertical and/or horizontal ext. & 1,762 & 48.93 & 0 & 100 \\
\hline hh includes other types of member & 1,762 & 30.31 & 0 & 100 \\
\hline share of non nuclear hh members & 1,762 & 28.22 & 0 & 96 \\
\hline hh includes non nuclear hh members & 1,762 & 66.07 & 0 & 100 \\
\hline Dakar & 1,762 & 28.13 & 0 & 100 \\
\hline Other urban area & 1,762 & 19.78 & 0 & 100 \\
\hline Rural & 1,762 & 52.09 & 0 & 100 \\
\hline Female hh head & 1,762 & 20.59 & 0 & 100 \\
\hline hh head is polygamous & 1,762 & 29.44 & 0 & 100 \\
\hline hh head is polygamous man & 1,762 & 23.51 & 0 & 100 \\
\hline hh head is polygamous woman & 1,762 & 5.93 & 0 & 100 \\
\hline hh head has no formal schooling & 1,762 & 64.68 & 0 & 100 \\
\hline age of hh head & 1,761 & 49.85 & 18 & 93 \\
\hline
\end{tabular}


Table 1b: Cell characteristics

\begin{tabular}{lcccc}
\hline & $\mathrm{N}$ & mean & Min & max \\
\hline Cell size & 4,293 & 3.25 & 1 & 15 \\
nb of children 0 - 4 y.o. in cell & 4,293 & 0.49 & 0 & 4 \\
nb of children 5 - 14 y.o. in cell & 4,293 & 0.86 & 0 & 7 \\
nb of children less than 15 y.o. in cell & 4,293 & 1.36 & 0 & 8 \\
nb of elderly over 66 y.o. in cell & 4,293 & 0.12 & 0 & 3 \\
cell with 2 adults (15+) or more \% & 4,293 & 46.69 & 0 & 100 \\
cell with 2 adults (21+) or more \% & 4,293 & 31.02 & 0 & 100 \\
cell without any children \% & 4,293 & 43.69 & 0 & 100 \\
cell with mother + children only \% & 4,293 & 47.44 & 0 & 100 \\
cell head is a woman \% & 4,293 & 56.81 & 0 & 100 \\
$\quad$ Excl. household head & 2,531 & 81.19 & 0 & 100 \\
cell head is the hh head \% & 4,293 & 40.23 & 0 & 100 \\
cell head is a male hh head\% & 4,293 & 31.95 & 0 & 100 \\
cell head is the spouse of hh head \% & 4,293 & 35.43 & 0 & 100 \\
cell head is a child of hh head \% & 4,293 & 8.86 & 0 & 100 \\
cell head is son/daughter in law of hh head \% & 4,293 & 2.15 & 0 & 100 \\
cell head is a sibling of hh head \% & 4,293 & 4.46 & 0 & 100 \\
cell head is a remote parent or non related \% & 4,293 & 5.48 & 0 & 100 \\
cell head is polygamous man \% & 4,293 & 10.55 & 0 & 100 \\
Excl. household head & 2,531 & 1.83 & 0 & 100 \\
cell head is polygamous woman \% & 4,293 & 22.18 & 0 & 100 \\
Excl. household head & 2,531 & 33.11 & 0 & 100
\end{tabular}

Source: PSF survey, authors' calculations using sampling weights.

\section{CONSUMPTION}

Contrary to traditional consumption surveys that only aim at estimating the level of household consumption, PSF is designed to approximate, as much as possible, individual access to resources. To design the questionnaire, we built on the fact that consumptions common to various cells in the household appeared clearly defined, as well as the responsibilities for paying for those consumptions, while cells’ own resources turned out to be not entirely pooled within the households. We conceived the survey so as to capture this detailed information.

Consumption data are collected in four distinct parts: food taken at home; household common consumption expenditures, including consumption of home-produced food; cell specific expenditures (such as expenses for clothing of the cell members, mobile phone, transportation, or food taken outside the home); and finally expenses shared between several 
cells (but not common to the whole household). From this data, per capita consumption is computed at the cell level. Common consumption expenditures are attributed to cells in proportion to the share of household members they include. Food expenditures are compiled based on a detailed account of who shares which meal and how much money is specifically used to prepare the meal. ${ }^{7}$ Each cell is ascribed its share in the food expenditures for the meals it joined in. For those meals, we have to assume food is shared evenly among participants. In fact, meals are often taken collectively from one common dish and individual food intakes are not observable. Though food expenditures for meals at home are often shared by the whole household, in $17 \%$ of households, subgroups emerge that take some or all of their meals separately, making room for unequal food consumption among household members. In addition, some members take parts of their meals outside the home. In any event, non-food expenditures naturally offer wider possibilities of divergence within households.

All the analyses presented in this paper exclude housing expenses. In this survey, only a very small share of the sample declares paying a rent for their dwelling. In fact, when everyone lives in adobe houses they built, as is the case in many parts of the country, the market price for the rental of such a dwelling simply doesn't exist. In such a situation, it is hardly possible to use the data to impute rents to home owners. We also exclude health expenditures, as inter personal differences in this dimension could reflect differences in needs. Hence, the term “total consumption” used in this paper refers to total consumption except housing (rent) expenses and health expenditures. ${ }^{8}$

\footnotetext{
7 The DQ, « Dépense quotidienne », the name Senegalese give to the amount of money a woman has at her disposal to buy the fresh ingredients for the meals of the day. One of the husband's duties is to provide the DQ. See Appendix A for more details on PSF survey design.

8 According to ANSD (2007), in 2005-2006, more than 80\% of households in Senegal were owners of their housing. Less than $16 \%$ were renting it, and only $2.6 \%$ in rural areas. This leaves a very small number of observations to compute meaningful imputed rents, unless a very large sample is available. Even in the ESPS sample (see Appendix A),
} 
It is important to note that the survey is designed so that information collected at the cell level is not the expenses made by the cell members, but actually those made by anyone, whether a member of the cell or the household or not, to the benefit of cell members. Long training insured that enumerators understood the nuance. For example, any expenses made by the head of household for the clothing of his children are recorded in the cell where the children are listed, more often than not that of their mother, distinct from the one of their father. In addition, the contributors to each of these expenditures are also registered.

A measure of total cell consumption is then constructed, adding expenditures specific to the cell and not shared with any other cell, plus the cell imputed part of the expenditures shared with other cells and of the household joint expenditures. This allows us to detect unequal consumption levels within households. Our most individualized measure of consumption is then the per capita cell consumption (or per adult equivalent consumption, if equivalence scales weighing children less than adults are used). ${ }^{9}$

In what follows, we therefore talk of per capita (or per adult equivalent) cell consumption when we measure consumption per capita at the cell level, while the term per capita (or per adult equivalent) household consumption designates the measure obtained with the more "traditional" way of measuring individual consumption, when individuals' access to resources is estimated from the aggregate household measure of consumption. Note nevertheless that the household consumption obtained by aggregating consumption of all cells is not similar to what would have been observed if consumption had been recorded directly at the household level. This point is detailed in appendix A. The comparison between the inequality and of rents paid by 171 households (on a total of 4987 rural households).

${ }_{9}^{9}$ To maintain comparability with existing works on poverty in Senegal, we use the same equivalence scale as that of Ndoye et al. (2009): one consumption unit for each adult, and one half for each child less than 15 years old. We test for the robustness of our results to this choice in section 5 . 
poverty assessments reached when using one or the other measure of consumption is central for the analysis presented in this paper.

\subsection{IMPLICATIONS FOR POVERTY AND INEQUALITY MEASUREMENT}

In this section we examine how the specific design of the PSF survey may impact the measurement of consumption compared to that of regular surveys, and how it may change inequality and poverty estimates based on household consumption levels.

Collecting data at the cell level implies that several members of the household are contributing information to the consumption survey. Since the household head doesn't directly observe all individual expenditures, in particular in a context where individual resources are not public knowledge within the household (see Boltz, Marazyan and Villar, 2015, Ziparo, 2014, Baland, Guirkinger and Mali, 2011), interviewing other household members allows to record expenditures that might otherwise have gone unnoticed. Proxy reporting as a potential source of underestimation was mentioned by Deaton (2005). Furthermore, the sheer fact that consumption is recorded in a more disaggregated manner might allow for a better recall (see Deaton 1997; Beegle et al. 2012). However, adding more respondents could also increase the amount of noise. If noise dominates, that should not introduce any systematic difference with regular household consumption surveys. Otherwise, increasing the number of respondents should lead to a more exhaustive recollection of consumption, and the consumption measured in PSF should be greater than in regular surveys, the more so for more complex households. One then expects the differences to increase with the number of cells.

We use data from the Enquête Suivi de la Pauvreté au Sénégal (ESPS) collected in 2005 to explore this conjecture. Since this survey is the one used by the Senegalese Government and 
international agencies to compute poverty and inequality statistics for the country, it is worth examining how the measures obtained from PSF differ from those obtained from ESPS. The comparison is far from trivial, however, because both surveys differ by many aspects that could be of consequences. Indeed, differences in design are well known to engender divergence in consumption measures, and it is important to try to assess the extent to which divergence between surveys is due to intra-household inequality rather than to any other source of disparity.

Appendix A details the comparison. First, stratification of the samples is different, with in particular a greater share of observations from the Dakar region in PSF than in ESPS. Sampling weights can be used to recover nationally representative samples from both surveys. But important differences persist even between weighted samples, and in order to improve comparability we chose to reweight ESPS observations using propensity scores obtained from regressions of the probability for a given observation to be in the PSF sample rather than the ESPS one, so as to make both samples exactly similar. Second, ESPS and PSF differ in their expenditure coverage, as ESPS includes taxes and ceremonial expenses that PSF does not collect. We therefore limit the comparison to the consumption of goods and services listed in both surveys. Further, for reasons explained in section 2.1, rents are also excluded. The final lists cover the exact same categories of goods but divided in 59 items in ESPS and 55 in PSF. Now, while ESPS treats food expenditures in the same way as any other expenses, the PSF questionnaire replicates the food spending patterns of Senegalese households by recording separately the DQ (“dépenses quotidienne”) spent on fresh food often on a daily basis, and the bulky purchases of staple food made less frequently by the household head. Finally, recall periods are also different, as ESPS imposes recall period that vary with the type of goods (from 1 month to 1 year) while PSF lets the respondent choose the recall period he feels corresponds best to the rhythm of purchase (12 modalities are proposed, from 1 day to 1 
year). Despite the restriction to strictly comparable sets of expenditures, the differences in the detail of the lists and in the recall periods can induce divergence in the measured consumption levels, as is now well documented in the literature (see Beegle et al. 2012 for a survey). In total, in this case, it is unclear whether any systematic divergence can be expected (Appendix A discusses this in more detail).

We observe that the total amount of annual expenditures per capita in PSF is significantly higher than in ESPS (328000 FCFA versus 285000, a difference of 15\%). We can compare how this varies by household structure (appendix Table A2.2) and we show that for individuals living alone and for single cell households there are no significant differences to speak of, while households composed of more cells display larger differences. Distance between consumption estimates of the two surveys is maximal for households with the most complex structure, those with several cells among which at least one contains members that are neither a spouse, nor a child or a grand-child of the household head. This pattern is very consistent with the idea that the share of the consumption directly observed by the household head decreases when the number of potential decision makers in terms of consumption increases. Mobilizing several respondents would then allow a better measure of actual household consumption. When concentrating on food, PSF records higher consumption for most types of households, consistent with the fact that the decomposition between DQ and infrequent food purchases permits a better recall of food spending (appendix Table A2.1). ${ }^{10}$

This difference in consumption estimates is in itself an important result. It suggests that traditional surveys in countries where individuals within the household do not fully share the information on their resources and on their expenditures are indeed likely to seriously underestimate consumption. In addition to varying with household structure, such

\footnotetext{
10 Clearly, collecting data at a more disaggregated level also induces a risk of additional measurement error. We will therefore assess the sensitivity of the results of our analysis to measurement errors.
} 
underestimation is probably more important for households in the upper part of the consumption distribution. In fact, poor households have less often several income earners or transfer recipients, so that opportunities for individual, unnoticed, expenditures are plausibly less frequent. Figure A.1 in appendix A confirms that the differences are more important at higher levels of consumption. ${ }^{11}$

As may be expected, we find more inequality in PSF than in ESPS data. Using per capita household expenditures, the Gini index is $47.1 \%$, quite a bit higher than what we find in ESPS (38.9\%) (using the series restricted so as to be comparable to PSF) and in the WDI (40.3\% for 2011). ${ }^{12}$ With such level of inequality, Senegal would be placed about 37 ranks higher in the ranking of countries by inequality level (computed from standard consumption data), from the 62nd position to the 25th one, between Venezuela and Chile. ${ }^{13}$ As we shall see in the next section, factoring in intra-household inequality will push Senegal even upward on the ladder of inequalities.

How does PSF modify the assessment of poverty? In order to answer this question we first need to define poverty. Two poverty lines are selected, following the basic needs approach. The lowest, nutrition, line corresponds to the cost of the food basket that provides at least $2400 \mathrm{kcal}$ per day. The second line is a basic needs poverty line, used as the national poverty threshold in Senegal. It is obtained by augmenting the food poverty threshold with the amount of resources that is necessary to cover individual basic needs other than nutrition. This amount is established through the observation of the average non-food consumption of households for

\footnotetext{
11 The fact that the underestimation of consumption is not distribution neutral pleads against anchoring poverty measure to National Accounts estimates of consumption, as it is likely to result in an overestimation of poor household consumption levels, following an argument made by Ravallion (2000).

12 It is slightly lower when using per adult equivalent measure of consumption. See Table C1 in the Appendix.

${ }^{13}$ Country ranking by GINI index (Most recent World Bank estimate).
} 
which food consumption per adult equivalent belongs to an interval of plus or minus 5\% around the food poverty threshold (see Appendix A).

Values of the two poverty lines for Dakar, other towns and rural areas separately are reported in table 2. The nutrition poverty line is very close to the \$1.25 (PPP 2005) international line (that would be equal to 366 CFA francs at the time of our survey). A \$2 line would correspond to 586 CFA francs.

Table 2: Value of the poverty thresholds

\begin{tabular}{lcc}
\hline & Nutrition poverty line & Basic needs poverty line \\
\hline Dakar & 396 & 835 \\
\hline Other towns & 369 & 647 \\
\hline Rural areas & 356 & 558 \\
\hline $\begin{array}{l}\text { Source: PSF survey, authors' calculations. Values are given in CFA francs. Numbers correspond to daily } \\
\text { expenditures per adult equivalent. Equivalent scale: 0.5: children 0 to 14 years old; 1: adults. }\end{array}$
\end{tabular}

Appendix Table A3.2 shows the values of the FGT indices (headcount, poverty gap and squared poverty gap) obtained with both surveys and poverty lines. Not much difference is found between the two surveys. PSF finds more people under the nutrition threshold $(16.7 \%$ versus $12.5 \%$ ), but less under the basic needs one (42.8\% versus $45 \%)$. Using the Datt and Ravallion decomposition framework (Datt and Ravallion 1992), we can decompose the difference in the poverty measures from the 2 surveys into its "growth" (difference in mean consumption) and "redistribution" (difference in inequality) components, and a residual. The fact that mean consumption is higher in the PSF data should lead to a decrease in poverty relative to ESPS, but the higher inequality plays in the opposite direction. Which of these components plays most is not a priori obvious. It happens that in our context, these two opposite biases happen to nearly exactly compensate each other. 


\section{INTRA-HOUSEHOLD INEQUALITIES}

\subsection{HOW IMPORTANT ARE INTRA-HOUSEHOLD INEQUALITIES?}

Table 3 reports various measures of inequality, first on total consumption and then on food and non-food consumption separately. The top panel of the table shows inequality statistics based on per capita household consumption, while the bottom part displays those based on per capita cell consumption.

As expected, the Gini index of inequality in the distribution of per capita household food expenditures is much lower than that of non-food spending, reaching $39.2 \%$ vs. $62.7 \%$.

Table 3: Inequality measures

\begin{tabular}{|c|c|c|c|c|c|}
\hline & Gini & $90 / 10$ & $75 / 25$ & $\begin{array}{c}\text { Mean log } \\
\text { dev }\end{array}$ & Theil-T \\
\hline \multicolumn{6}{|c|}{ Per capita household consumption } \\
\hline Total consumption & $\begin{array}{l}47.11 \\
(1.06)\end{array}$ & $\begin{array}{c}7.70 \\
(0.36)\end{array}$ & $\begin{array}{c}3.02 \\
(0.13)\end{array}$ & $\begin{array}{c}0.38 \\
(0.02)\end{array}$ & $\begin{array}{c}0.43 \\
(0.03)\end{array}$ \\
\hline Non-food consumption & $\begin{array}{l}62.72 \\
(1.21)\end{array}$ & $\begin{array}{l}19.48 \\
(1.10)\end{array}$ & $\begin{array}{l}5.23 \\
(0.28)\end{array}$ & $\begin{array}{c}0.77 \\
(0.03)\end{array}$ & $\begin{array}{c}0.82 \\
(0.05)\end{array}$ \\
\hline Food consumption & $\begin{array}{l}39.17 \\
(0.71)\end{array}$ & $\begin{array}{c}5.93 \\
(0.29)\end{array}$ & $\begin{array}{c}2.44 \\
(0.07)\end{array}$ & $\begin{array}{c}0.26 \\
(0.01)\end{array}$ & $\begin{array}{c}0.27 \\
(0.01)\end{array}$ \\
\hline \multicolumn{6}{|c|}{ Per capita cell consumption } \\
\hline Total consumption & $\begin{array}{l}49.67 * * * \\
(1.02)\end{array}$ & $\begin{array}{l}8.72 * * * \\
(0.42)\end{array}$ & $\begin{array}{c}3.12 \\
(0.09)\end{array}$ & $\begin{array}{l}0.42 * * * \\
(0.02)\end{array}$ & $\begin{array}{l}0.50^{* * *} \\
(0.03)\end{array}$ \\
\hline Non-food consumption & $\begin{array}{l}67.16^{* * *} \\
(1.09)\end{array}$ & $\begin{array}{l}26.39 * * * \\
(1.54)\end{array}$ & $\begin{array}{l}5.91 \text { *** } \\
(0.27)\end{array}$ & $\begin{array}{l}0.92 * * * \\
(0.03)\end{array}$ & $\begin{array}{l}1.00^{* * *} \\
(0.05)\end{array}$ \\
\hline Food consumption & $\begin{array}{l}40.39 * * * \\
(0.69)\end{array}$ & $\begin{array}{l}6.48^{* * *} \\
(0.26)\end{array}$ & $\begin{array}{l}2.54 * * \\
(0.08)\end{array}$ & $\begin{array}{l}0.27 * * * \\
(0.01)\end{array}$ & $\begin{array}{l}0.29 * * * \\
(0.01)\end{array}$ \\
\hline
\end{tabular}

Using per capita cell consumption rather than per capita household consumption, inequality levels are revised upward. ${ }^{14}$ Most of the difference comes from the inequality of non-food

\footnotetext{
${ }^{14}$ Standard errors in Table 3 cannot be used to assess the significance of the differences between inequality indices, since household and cell level indices are computed on the same sample. In order to account for the resulting
} 
consumption, while inequality in food consumption is only mildly affected. The Gini of total consumption increases to nearly 50\% when each individual is attributed their cell per capita consumption level (and that of non-food consumption to 67.2\%). This level of inequality would place Senegal just below Honduras in the countries ranking, another 8 ranks hike from where the country stands when intra-household inequalities are not accounted for.

How important are intra-household inequalities in the building of inter-personal inequalities? To answer this question we compute the Theil $\mathrm{T}$ index, which we decompose between intraand inter-household inequalities (Table 4). The decomposition indicates that more than 18\% of total inequalities in non-food expenditures occur within households. As expected, in the case of food expenditures the share of intra-household inequality is much lower, reaching only $6 \%$ of the total.

Assuming equal sharing of food between household members eating together underestimates actual intra-household inequality in food consumption. In fact, although we cannot directly observe it, there are some indications in the literature that in African contexts there exist intra-household inequalities in the access to nutritional inputs (see e.g. Dercon and Krishnan, 2000, D’Souza and Tandon, forthcoming, or Brown et al., forthcoming).

Table 4: Inequality decomposition

\begin{tabular}{lccc}
\hline & $\begin{array}{c}\text { Theil T } \\
\text { within }\end{array}$ & $\begin{array}{c}\text { Theil T } \\
\text { between }\end{array}$ & $\begin{array}{c}\text { Share } \\
\text { within }\end{array}$ \\
\hline All consumption & 0.07 & 0.43 & 13.85 \\
& $(0.01)$ & $(0.03)$ & $(1.34)$ \\
Non-food consumption & 0.18 & 0.82 & 17.78 \\
& $(0.02)$ & $(0.05)$ & $(1.54)$ \\
Food consumption & 0.02 & 0.27 & 6.26 \\
& $(0.00)$ & $(0.01)$ & $(0.63)$ \\
\hline Source: PSF survey, N=1762 households. Bootstrap standard errors (250 replications) between \\
parentheses.
\end{tabular}

correlation between indices, standard errors of differences have been computed using 250 bootstrap replications. Results are presented in Appendix B, Table B1. Since all inequality indices used in this paper can be shown to be asymptotically normally distributed (see references in Appendix B), the usual t tests can be used to assess significance. 
For total consumption, the share of intra-household inequality is nearly $14 \%$ of total inequality. Whether this is a large share or not is difficult to assess without a comparison point. We can think of one external comparison, that given by Klasen and Lahori (2016), who estimate intra-household inequality at about $30 \%$ of total inequality in India. This comparison is interesting, but not conclusive since these authors base their analysis on multidimensional poverty indices, not on consumption measures, so that the comparison cannot be done directly. Moreover, Klasen and Lahori estimates refer to India, a country that has an income per capita much greater than Senegal (1750US\$ vs. 1042US\$, in 2010 constant dollars, according to the World Development Indicators), leaving a larger margin for non-subsistence consumption expenditures that are likely to be more unequally shared than those expenditures dedicated to subsistence needs (unless the household is so poor that it has to engage into a lifeboat strategy, insuring enough resources to its income earning members - section 3.2. suggests this doesn’t apply in our context).

To obtain a comparison point, it is possible to construct a counterfactual situation from our data that maximizes intra-household inequality. In order to do this, we simulated a distribution where everyone gets his observed share of food consumption and of consumption common to the household (such as electricity, water, furniture...). Note that this shared consumption amounts to $68 \%$ of total consumption on average. We then imagine an amazingly unfair household head capturing any extra resource and attribute all the remaining consumption to his/her cell, thereby maximizing intra-household inequality. When doing this, the Theil index of this distribution reaches 0.69 , and the within-household component amounts to 0.23 , that is $33 \%$ of total consumption inequality. Gauging our result by this hypothetical counterfactual situation, it seems that the observed within-household inequality is very significant, reaching $42 \%$ of this maximum. 


\subsection{THE CORRELATES OF INTRA-HOUSEHOLD INEQUALITY}

Which households are more likely to be unequal? Is it related to the total amount of expenditure? To the household structure? To the head's characteristics? In this section, we examine the correlates of being an unequal household focusing on the household structure, and show how the specificity of the PSF questionnaire allows to gain new insights on the determinants of intra-household inequality.

In table 5, we present the correlates of the within household Theil index, both for consumption as a whole and then separately for food and non-food expenditures.

Household structure clearly plays a role in explaining intra-household inequality. It is worth noting that this might be difficult to pin down with standard household surveys that only record the relationship of each household member to the household head. The first 2 columns of table 5 compare the description of the relation between inequality and household structure obtained from a regression using only variables that could be retrieved from a traditional survey, to what can be exhibited with the more detailed information on household structure that PSF contains. Column (1) describes household structure with variables counting the number of children below age 5 , those between 5 and 15, the number of adult women between 15 and 65 years of age, and the number of elderly members. It also includes a dummy variable if the household doesn't embrace any horizontal extension, i.e. if all members are either the wife, the parents, the children or the grand-children of the household head. The first column only indicates that the level of intra household inequality increases with the number of children aged 5 to 14 . As this might reflect difference in needs that are not captured by the per capita measure of individual consumption, it is not very revealing. The second column makes clear that, even controlling for the size and the age-gender composition of the household, its precise organisation matters. Extended households with more than two cells, whether they are polygamous households or include cells headed by relatives in addition to the head's conjugal 
unit, have more unequal resource allocation than any other household types. On the other hand, when the household head has no spouse in the household, resource allocation appears less unequal. ${ }^{15} 16$ Note also that, even though there is very little inequality in food consumption that we can measure, households in which meals taken at home are not shared in by all members are significantly more unequal overall than those where everyone eats together. Interestingly, in addition to the fact that eating together mechanically reduces intrahousehold inequality in food consumption, it is also correlated to lower inequality in non-food consumption, suggesting that taking all meals together is a symptom of a higher level of resource pooling. ${ }^{17}$ Adding this variable doesn't affect the correlation of the household structure variables with the within household inequality level. Results are reported in column (3).

Finally, it appears that intra-household inequality increases with household total consumption, suggesting that it is not driven by lifeboat strategies.18 Further, it is worth noting that this result doesn't support one of the key assumptions made in the literature on estimating individual shares of total spending from household aggregates (following Dunbar et al. 2013), backing up the idea that collective household models might not be well adapted to the context under study.

When looking separately at food and non-food expenditures, the aggregate pattern appears very close to that of non-food consumption. In fact, hardly anything explains inequality in

\footnotetext{
$1583 \%$ of households headed by a head without a co-residing spouse are female headed.

16 Whether the household head has ever been to formal school or not doesn't appear to be correlated with the withinhousehold Theil in any of the specifications. The same holds for the polygamy of the household head. (Results not reported here).

${ }^{17}$ Systematic meal sharing is more frequent for the poorest households (see table E3, appendix E).

${ }^{18}$ Appendix E reports the results using deciles of per capita household consumption rather than log per capita household consumption, and the relationship with inequality seems rather linear.
} 
food consumption, apart, in a rather mechanical way, from the observation made above that all household members take all their meals together ${ }^{19}$. Within household Theil of food expenditures is also lower for households with more adult women and for large households with more than 3 cells, none of them headed by a spouse of the head.

In total, household structure (beyond and above its age-gender composition) and household living arrangements are strongly correlated with the observed intra-household inequality.

\footnotetext{
${ }^{19}$ Without this variable, the R-square of the corresponding regression is 0.016 , instead of 0.155 .
} 
Table 5: Correlates of Within household Inequality

\begin{tabular}{|c|c|c|c|c|c|}
\hline & (1) & (2) & (3) & (4) & (5) \\
\hline VARIABLES & Theil T within & Theil $\mathrm{T}$ within & Theil T within & $\begin{array}{l}\text { Theil T within - } \\
\text { food }\end{array}$ & $\begin{array}{c}\text { Theil T within - } \\
\text { nonfood }\end{array}$ \\
\hline \multirow[t]{2}{*}{ Dakar } & $-0.0230 *$ & -0.0177 & $-0.0208^{*}$ & 0.00223 & $-0.107^{* * *}$ \\
\hline & $(0.0128)$ & $(0.0127)$ & $(0.0125)$ & $(0.00741)$ & $(0.0219)$ \\
\hline \multirow[t]{2}{*}{ Other urban areas } & -0.0171 & -0.00960 & -0.0110 & 0.00395 & $-0.0668 * * *$ \\
\hline & $(0.0106)$ & $(0.0107)$ & $(0.0105)$ & $(0.00528)$ & $(0.0198)$ \\
\hline \multirow[t]{2}{*}{ Log per cap. hh cons. } & $0.0379 * * *$ & $0.0380 * * *$ & $0.0369 * * *$ & -0.00425 & $0.0533 * * *$ \\
\hline & $(0.00860)$ & $(0.00862)$ & $(0.00844)$ & $(0.00283)$ & $(0.0116)$ \\
\hline \multirow[t]{2}{*}{ Household size } & 0.00168 & 0.000615 & 0.000128 & 0.00141 & -0.00237 \\
\hline & $(0.00186)$ & $(0.00181)$ & $(0.00171)$ & $(0.00150)$ & $(0.00315)$ \\
\hline \multirow[t]{2}{*}{$\mathrm{Nb}$ of cells in the hh } & & -0.00218 & -0.000857 & 0.00353 & 0.00104 \\
\hline & & $(0.00545)$ & $(0.00560)$ & $(0.00245)$ & $(0.0124)$ \\
\hline \multirow[t]{2}{*}{$\mathrm{Nb}$ of children 0-4 y.o } & 0.00512 & 0.00512 & 0.00439 & -0.00127 & $0.0138 * *$ \\
\hline & $(0.00320)$ & (0.00329) & $(0.00326)$ & $(0.00271)$ & $(0.00659)$ \\
\hline \multirow[t]{2}{*}{ Nb of children 5-14 y.o } & $0.00454 *$ & $0.00515^{*}$ & $0.00558 * *$ & -0.00197 & $0.0165^{* * *}$ \\
\hline & $(0.00270)$ & $(0.00268)$ & $(0.00266)$ & $(0.00190)$ & $(0.00583)$ \\
\hline \multirow[t]{2}{*}{ Nb of women 15-65 y.o. } & -0.00391 & -0.00337 & -0.00422 & $-0.00492 * *$ & -0.00322 \\
\hline & $(0.00301)$ & $(0.00310)$ & $(0.00316)$ & $(0.00202)$ & $(0.00608)$ \\
\hline \multirow[t]{2}{*}{$\mathrm{Nb}$ of elderly $66+$ y.o } & 0.00626 & 0.00449 & 0.00412 & -0.00126 & $9.53 \mathrm{e}-05$ \\
\hline & $(0.00597)$ & $(0.00617)$ & $(0.00620)$ & $(0.00315)$ & $(0.0117)$ \\
\hline \multirow[t]{2}{*}{ 2-cell hh, head + other } & & $-0.0219 * * *$ & $-0.0229 * * *$ & -0.000136 & $-0.0791^{* * *}$ \\
\hline & & $(0.00748)$ & $(0.00756)$ & $(0.00575)$ & $(0.0152)$ \\
\hline \multirow{2}{*}{$\begin{array}{l}3+- \text { cell hh: head and } \\
\text { wives. }\end{array}$} & & $0.0232 * *$ & $0.0225^{* *}$ & 0.00328 & $0.0644^{* *}$ \\
\hline & & (0.0109) & $(0.0107)$ & $(0.00811)$ & $(0.0276)$ \\
\hline \multirow{2}{*}{$\begin{array}{l}\text { 3+-cell hh: head, wife } \\
\text { (wives), + other }\end{array}$} & & $0.0208^{*}$ & $0.0208^{*}$ & -0.00210 & 0.0308 \\
\hline & & $(0.0106)$ & $(0.0108)$ & $(0.00417)$ & $(0.0219)$ \\
\hline \multirow{2}{*}{$\begin{array}{l}\text { 3+-cell hh: head + others } \\
\text { (no spouse) }\end{array}$} & & $-0.0159 *$ & $-0.0217^{* *}$ & $-0.0186 * * *$ & $-0.0425^{* *}$ \\
\hline & & $(0.00853)$ & $(0.00913)$ & $(0.00560)$ & $(0.0198)$ \\
\hline \multirow{2}{*}{$\begin{array}{l}\text { HH without horizontal } \\
\text { extensions }\end{array}$} & 0.00737 & & & & \\
\hline & $(0.00612)$ & & & & \\
\hline \multirow[t]{2}{*}{ All meals taken together } & & & $-0.0538 * * *$ & $-0.0786 * * *$ & $-0.0395^{*}$ \\
\hline & & & $(0.0129)$ & $(0.0145)$ & $(0.0202)$ \\
\hline \multirow[t]{2}{*}{ Constant } & $-0.432 * * *$ & $-0.423^{* * *}$ & $-0.360 * * *$ & $0.125^{* * * *}$ & $-0.440 * * *$ \\
\hline & $(0.102)$ & $(0.101)$ & $(0.0997)$ & $(0.0421)$ & $(0.141)$ \\
\hline Observations & 1,426 & 1,426 & 1,426 & 1,426 & 1,426 \\
\hline R-squared & 0.067 & 0.080 & 0.109 & 0.155 & 0.105 \\
\hline
\end{tabular}

Source: PSF survey, authors' calculations. $\mathrm{N}=1426$ households with at least two cells. OLS regressions. Additional controls: religion and ethnicity of the household head. Reference category for household structure is a household with two cells: head and spouse. "2-cell hh: head + other" refers to households composed of 2 cells, where the second cell is not that of the head's spouse. " $3+-$-cell hh: head and wives" refers to polygamous households, where all the cells are headed by members of the conjugal unit. " $3+$-cell hh: head, wife (wives) + other" refers to households with at least 3 cells and where at least one of the cells is not headed by a spouse of the head. " $3+-$ cell hh: head+others (no wife)" refers to households with more than 3 cells and where none of them is headed by a spouse of the household head. Robust standard errors in parentheses, clustered at the PSU level, ${ }^{* * *} \mathrm{p}<0.01,{ }^{* *} \mathrm{p}<0.05,{ }^{*} \mathrm{p}<0.1$ 


\section{IMPACT ON POVERTY DiagnOSTIC}

\subsection{Do INTRA-HOUSEHOLD INEQUALITIES MODIFY THE EXTENT OF POVERTY?}

Computing poverty estimates using per adult equivalent cell rather than household consumption allows factoring in intra-household inequality. How does it impact poverty? As shown in table 6, using per adult equivalent cell rather than household consumption leads to revise poverty levels upwards, both for the headcount and the poverty gap.

The results show that the household level approach leads to an underestimation of poverty rates by 0.3 to 3.6 percentage points, depending on the poverty line and the residential area. This corresponds to an underestimation of the prevalence of poverty by $8.2 \%$ (basic needs threshold) and 9.3\% (nutrition threshold) at the national level. The underestimation is particularly severe in Dakar (14\% for the basic needs threshold), as could have been expected, given the especially high intra-household inequality in that area.

Table 6: Poverty estimates

\begin{tabular}{|c|c|c|c|c|}
\hline & \multicolumn{2}{|c|}{ Nutrition poverty line } & \multicolumn{2}{|c|}{ Basic needs poverty line } \\
\hline & $\begin{array}{l}\text { Headcount } \\
\text { Index }\end{array}$ & $\begin{array}{l}\text { Poverty gap } \\
\text { Index }\end{array}$ & $\begin{array}{l}\text { Headcount } \\
\text { Index }\end{array}$ & $\begin{array}{l}\text { Poverty gap } \\
\text { index }\end{array}$ \\
\hline \multicolumn{5}{|c|}{$\begin{array}{l}\text { Per adult equivalent } \\
\text { household consumption }\end{array}$} \\
\hline National & $\begin{array}{r}16.69 \\
(1.11)\end{array}$ & $\begin{array}{l}4.24 \\
(0.38)\end{array}$ & $\begin{array}{r}42.78 \\
(1.33)\end{array}$ & $\begin{array}{r}14.26 \\
(0.64)\end{array}$ \\
\hline Dakar & $\begin{array}{r}1.78 \\
(0.80)\end{array}$ & $\begin{array}{r}0.32 \\
(0.13)\end{array}$ & $\begin{array}{r}25.57 \\
(2.37)\end{array}$ & $\begin{array}{r}6.31 \\
(0.67)\end{array}$ \\
\hline Other urban & $\begin{array}{r}9.16 \\
(2.05)\end{array}$ & $\begin{array}{r}1.98 \\
(0.58)\end{array}$ & $\begin{array}{r}33.69 \\
(2.93)\end{array}$ & $\begin{array}{r}9.99 \\
(1.19)\end{array}$ \\
\hline Rural & $\begin{array}{r}29.81 \\
(2.04)\end{array}$ & $\begin{array}{r}7.81 \\
(0.71)\end{array}$ & $\begin{array}{r}58.09 \\
(2.12)\end{array}$ & $\begin{array}{r}21.36 \\
(1.02)\end{array}$ \\
\hline \multicolumn{5}{|c|}{$\begin{array}{l}\text { Per adult equivalent cell } \\
\text { consumption }\end{array}$} \\
\hline National & $\begin{array}{r}18.24^{* * *} \\
(1.00)\end{array}$ & $\begin{array}{c}5.12 * * * \\
(0.37)\end{array}$ & $\begin{array}{r}46.29 * * * \\
(1.26)\end{array}$ & $\begin{array}{c}16.04^{* * *} \\
(0.64)\end{array}$ \\
\hline Dakar & $\begin{array}{l}2.07 \\
(0.61)\end{array}$ & $\begin{array}{c}0.47 * * * \\
(0.17)\end{array}$ & $\begin{array}{r}29.14 * * * \\
(2.02)\end{array}$ & $\begin{array}{r}7.94 * * * \\
(0.70)\end{array}$ \\
\hline Other urban & $\begin{array}{r}11.23 * * \\
(1.95)\end{array}$ & $\begin{array}{c}2.93 * * * \\
(0.66)\end{array}$ & $\begin{array}{r}37.12 * * * \\
(2.53)\end{array}$ & $\begin{array}{r}11.61^{* * * *} \\
(1.11)\end{array}$ \\
\hline Rural & $\begin{array}{r}32.00 * * * \\
(1.87)\end{array}$ & $\begin{array}{c}9.15 * * * \\
(0.70)\end{array}$ & $\begin{array}{r}61.60 * * * \\
(1.82)\end{array}$ & $\begin{array}{c}23.31 * * * \\
(0.99)\end{array}$ \\
\hline
\end{tabular}


As seen in Table 6, the difference in poverty measures based on per adult equivalent household or cell consumption depends on the choice of poverty line. In appendix D we assess the sensitivity of the results to this choice. We find that the difference between poverty rates is significant for a large range of poverty lines.

\subsection{BEING POOR AMONG THE NON-POOR.}

The evidence of intra-household inequality raises the possibility that some poor individuals might go unnoticed because they live in households where not everyone is poor and that may not be identified as poor by poverty measures based on standard assessments of consumption levels. In fact, poor cells can be found within non-poor households and, inversely, non-poor cells within poor households. ${ }^{20}$ This is documented in figure 1 and table 7 . In figure 1 we plot the ranking of cells depending on whether one uses household or cell level per adult equivalent consumption for the first two quartiles of the distribution. The vertical and horizontal lines in the graphic shows the rank of the cell that is just at the nutrition (left panel, first quartile) or basic need threshold (right panel, second quartile). The figure shows that there is a substantial reordering of cells depending on how consumption is measured. This has implications on the identification of the poor, with all cells located in the top left and in the bottom right parts of both panels being misclassified, when using household level consumption, as being either non poor, while being poor (top left) or poor while being non poor (bottom right). Table 7 ventilates the distribution of households in 4 categories according to the poverty status of the household and the presence or not of cells with a different poverty status (columns 1 and 2). The distribution of cells and individuals according to their poverty status and that of their household is given in columns 3 to 6 . We observe that the proportion

\footnotetext{
${ }^{20}$ See Brown et al., (forthcoming) for similar findings based on nutrition.
} 
of poor cells belonging to a non-poor household varies between $2.6 \%$ and $5.1 \%$ of cells depending on the poverty threshold ( $4^{\text {th }}$ column). Comparing with the population percentages ( $6^{\text {th }}$ column), we observe that poor cells in non-poor households seem to be large cells.

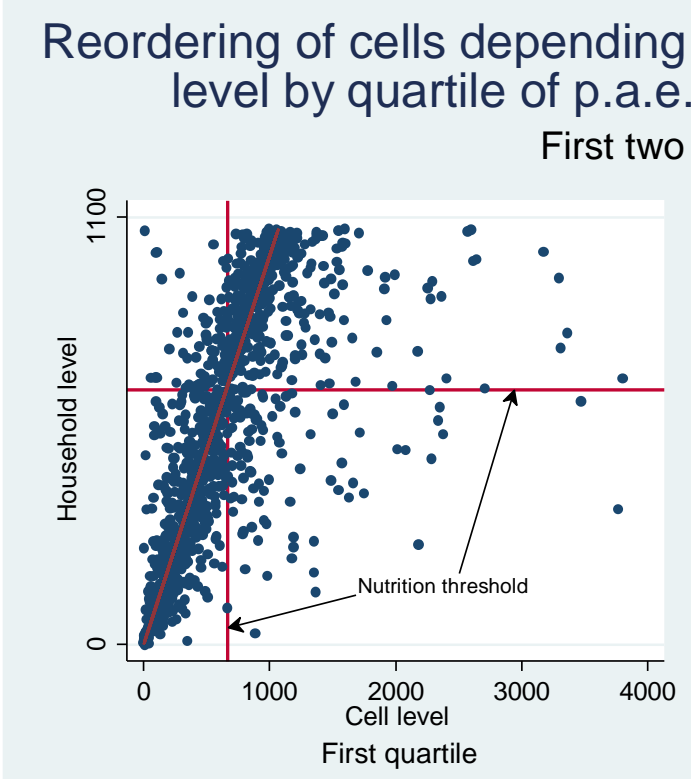

Source: PSF survey, authors' calculations. $\mathrm{N}=1070$ (first quartile) and 1072 cells (second quartile). For each graph, horizontal axis shows the ranking of cells based on cell level consumption aggregate, while vertical axis shows the ranking based on household level consumption aggregate.

Equivalence scale: 1 for adults, 0.5 for children less than 15.

Figure 1

In total, using the basic needs poverty threshold, $13.7 \%{ }^{21}$ of non-poor households include at least one poor cell, which means that $10.8 \%$ of the members of non-poor households are, in fact, poor, or that $13.4 \%$ of the poor live in non-poor households. This suggests that measuring poverty using a well-being measure computed at the household level can lead to an underestimation of the extent of poverty, but more importantly, to serious missidentification of the poor. 
Table 7: Distribution of the poor by Poverty Status of their household

\begin{tabular}{|c|c|c|c|c|c|c|}
\hline & \multicolumn{2}{|c|}{ Households } & \multicolumn{2}{|c|}{ Cells } & \multicolumn{2}{|c|}{ Individuals } \\
\hline & $\mathrm{N}$ & $\%$ & $\mathrm{~N}$ & $\%$ & $\mathrm{~N}$ & $\%$ \\
\hline & (1) & (2) & (3) & (4) & (5) & (6) \\
\hline \multicolumn{7}{|l|}{ Basic needs threshold } \\
\hline Poor in non-poor households & 158 & 8.97 & 219 & 5.10 & 865 & 6.18 \\
\hline Poor in poor households & 446 & 25.31 & 1,514 & 35.27 & 5,610 & 40.11 \\
\hline Non-poor in poor households & 162 & 9.19 & 181 & 4.22 & 374 & 2.67 \\
\hline Non-poor in non-poor households & 996 & 56.53 & 2,379 & 55.42 & 7,139 & 51.04 \\
\hline Poor in non-poor households & 79 & 4.48 & 110 & 2.56 & 419 & 3.00 \\
\hline Poor in poor households & 136 & 7.72 & 556 & 12.95 & 2,133 & 15.25 \\
\hline Non-poor in poor households & 84 & 4.77 & 100 & 2.33 & 201 & 1.44 \\
\hline Non-poor in non-poor households & 1,463 & 83.03 & 3,527 & 82.16 & 11,235 & 80.32 \\
\hline \multicolumn{7}{|c|}{$\begin{array}{l}\text { Source: PSF survey, authors' calculations. Poverty status based on per adult equivalent consumption. Equivalent scale: } 0.5 \text { : children } \\
0 \text { to } 14 \text { years old; 1: adults. } \\
\text { Reading note: The line "poor in non-poor households" gives the number (and share) of non-poor households containing at least } \\
\text { one poor cell; then, the number of poor cells found in non-poor households; and finally, the number of poor individuals found in } \\
\text { non-poor households. Following lines are to be read in a similar way. The second line gives numbers for poor households where } \\
\text { everyone is poor, the third line for poor households containing at least one non-poor cell, and the fourth line for non-poor } \\
\text { households where all the cells are non-poor. }\end{array}$} \\
\hline
\end{tabular}

In non-poor households that include at least one poor cell, investigating who is particularly at risk of being poor could be of first order policy relevance. A simple logit estimate of the probability for non-poor households of comprising at least one poor cell shows unsurprisingly that richer households are less likely to be in this case, and, controlling for household per adult equivalent consumption, complex households, in urban areas, whose head has no formal schooling are more likely to have some poor members. This is mitigated if they take together all the meals eaten at home (see table E2 in appendix). An analysis of the probability of being the head of a poor cell in a non-poor household, taking household fixed-effect into account (conditional logit) is presented in Table 8. Column 1 shows that large cells, those headed by the wife of the head and with many young children, are more likely to be in this situation. Some of it might be driven by differences in needs not properly accounted for by the equivalence scales. Generally, the cell of the household head is the least likely to be a poor cell in a non-poor household. More interesting is the fact that cells headed by distant family members are more vulnerable. Most of those factors are particularly important for household whose consumption places them in the bottom quintile of the distribution of non-poor household (column 3). In richer households (in the top 4 quintiles - column 2), apart from 
female headed cells, those at risk of poverty are only those headed by a distant relative of the household head.

Table 8: Probability of being a poor cell in a non-poor household (household fixed effects).

\begin{tabular}{|c|c|c|c|}
\hline VARIABLES & $\begin{array}{c}(1) \\
\text { All }\end{array}$ & $\begin{array}{c}(2) \\
-80 \% \text { richest } \\
\mathrm{hh}-\text { non-poor }\end{array}$ & $\begin{array}{c}\text { (3) } \\
\text { 20\% poorest } \\
\text { hh - non-poor }\end{array}$ \\
\hline Cell head is a woman & $\begin{array}{l}1.860^{*} \\
(0.658)\end{array}$ & $\begin{array}{c}2.475 * * \\
(1.035)\end{array}$ & $\begin{array}{c}1.226 \\
(0.915)\end{array}$ \\
\hline Age of cell head & $\begin{array}{l}1.032 * * \\
(0.0147)\end{array}$ & $\begin{array}{c}1.021 \\
(0.0172)\end{array}$ & $\begin{array}{c}1.061^{*} \\
(0.0342)\end{array}$ \\
\hline Cell size & $\begin{array}{l}1.174^{*} \\
(0.105)\end{array}$ & $\begin{array}{c}1.135 \\
(0.116)\end{array}$ & $\begin{array}{l}1.508 * \\
(0.342)\end{array}$ \\
\hline $\mathrm{Nb}$ of children 0 - 4 y.o. in cell & $\begin{array}{c}1.640 * * \\
(0.325)\end{array}$ & $\begin{array}{l}1.536 * \\
(0.380)\end{array}$ & $\begin{array}{c}1.462 \\
(0.566)\end{array}$ \\
\hline Nb of children 5 - 14 y.o. in cell & $\begin{array}{c}0.981 \\
(0.144)\end{array}$ & $\begin{array}{c}0.967 \\
(0.165)\end{array}$ & $\begin{array}{c}0.826 \\
(0.279)\end{array}$ \\
\hline Cell head is a child of hh head & $\begin{array}{c}2.114 \\
(1.134)\end{array}$ & $\begin{array}{c}1.484 \\
(1.008)\end{array}$ & $\begin{array}{c}6.139 \\
(7.006)\end{array}$ \\
\hline Cell head is parent or grand-parent of hh head & $\begin{array}{c}0.964 \\
(0.726)\end{array}$ & $\begin{array}{c}1.079 \\
(0.893)\end{array}$ & $\begin{array}{c}1.051 \\
(1.885)\end{array}$ \\
\hline Cell head is a sibling of hh head & $\begin{array}{c}2.341 \\
(1.323)\end{array}$ & $\begin{array}{c}2.017 \\
(1.262)\end{array}$ & $\begin{array}{c}2.229 \\
(2.884)\end{array}$ \\
\hline Cell head other family link to hh head & $\begin{array}{c}2.830 * * \\
(1.231)\end{array}$ & $\begin{array}{l}2.382^{*} \\
(1.220)\end{array}$ & $\begin{array}{c}3.505 \\
(3.475)\end{array}$ \\
\hline Cell head is the spouse of hh head & $\begin{array}{l}2.134 * \\
(0.843)\end{array}$ & $\begin{array}{c}1.656 \\
(0.777)\end{array}$ & $\begin{array}{l}4.328 * \\
\text { (3.619) }\end{array}$ \\
\hline Cell head is literate & $\begin{array}{c}0.864 \\
(0.302)\end{array}$ & $\begin{array}{c}0.939 \\
(0.396)\end{array}$ & $\begin{array}{c}0.857 \\
(0.545)\end{array}$ \\
\hline Cell head has no formal schooling & $\begin{array}{c}1.447 \\
(0.548)\end{array}$ & $\begin{array}{c}1.114 \\
(0.498)\end{array}$ & $\begin{array}{l}5.132 * \\
(4.693)\end{array}$ \\
\hline $\begin{array}{l}\text { Observations } \\
\text { Pseudo-R2 }\end{array}$ & $\begin{array}{l}501 \\
0.23\end{array}$ & $\begin{array}{l}338 \\
0.22\end{array}$ & $\begin{array}{l}163 \\
0.34\end{array}$ \\
\hline
\end{tabular}

\subsection{ARE THE POOR IN NON-POOR HOUSEHOLDS AS POOR?}

How poor are the poor that live in non-poor households? A natural question is that of whether the intensity of poverty is lower for them than for those who live in households where everyone is poor. Table 9 gives some elements to answer this question by presenting the poverty gap for the poor who live in non-poor households (Columns c1 and c2) and 
comparing it to that of the poor from homogeneously poor households (a1 and a2), and from poor households with non-poor members (b1 and b2).

Table 9: Poverty gaps for poor cells in poor and non-poor households

\begin{tabular}{lcccccc}
\hline & \multicolumn{3}{c}{ Nutrition poverty threshold } & \multicolumn{3}{c}{ Basic needs poverty threshold } \\
\hline \multirow{2}{*}{ National } & $(\mathrm{a} 1)$ & $(\mathrm{b} 1)$ & $(\mathrm{c} 1)$ & $(\mathrm{a} 2)$ & (b2) & (c2) \\
& 32.22 & 28.15 & 14.39 & 40.50 & 30.48 & 14.17 \\
Dakar & $(1.66)$ & $(1.93)$ & $(2.08)$ & $(1.00)$ & $(1.38)$ & $(0.84)$ \\
& 29.98 & 30.14 & 9.62 & 31.13 & 26.84 & 17.96 \\
Other urban areas & $(10.07)$ & $(5.97)$ & $(3.25)$ & $(2.02)$ & $(2.09)$ & $(1.71)$ \\
& 28.88 & 29.80 & 17.04 & 37.00 & 32.07 & 10.53 \\
Rural areas & $(3.11)$ & $(6.63)$ & $(3.68)$ & $(2.55)$ & $(3.78)$ & $(2.07)$ \\
& 32.61 & 27.75 & 14.19 & 43.48 & 31.31 & 13.13 \\
& $(1.75)$ & $(1.96)$ & $(2.69)$ & $(1.14)$ & $(1.77)$ & $(1.24)$ \\
\hline
\end{tabular}

Source: PSF survey, authors' calculations. Poverty status based on per adult equivalent consumption. Bootstrap standard errors are between parentheses (250 replications). Equivalent scale: 0.5 : children 0 to 14 years old; 1 : adults. Columns (a1) and (a2) show the value of the poverty gap for poor cells in poor households in which all cells are found poor; columns (b1) and (b2) show the value of the poverty gap for poor cells in poor households, in which some cells are found not poor; and columns (c1) and (c2) show the value of the poverty gap for poor cells in non-poor households.

Table 9 clearly shows that the poor in non-poor households are less poor than other poor. At the national level, the poverty gap for this group is only half that of the poor who live in poor households that contain non-poor members. At the basic needs threshold, it reaches only 35\% of the poverty gap of the poor in poor households. This is understandable, as intra-household inequality is more likely to push part of the household members on the other side of the poverty line if the household as a whole is not too far from it. It suggests that the "invisible poor” are likely to be among the least poor of the poor.

\section{ROBUSTNESS CHECKS}

\subsection{SENSITIVITY TO MEASUREMENT ERROR}

We assess the robustness of the above estimates to various amounts of measurement error, as inequality measures can be particularly sensitive to this source of bias. Following Chesher and 
Schluter (2002), we first produce overall inequality estimates correcting for some amount of measurement error. Assuming an error to signal variances ratio of $10 \%$ (resp. 20\%) would decrease the estimated Gini from 47.1 to $45.3 \%$ (resp. $43.6 \%$ ) and the Theil-T from 42.8 to 39.5 (resp. 36.1). ${ }^{22}$ The assumed variance of measurement error needs to reach $40 \%$ of that of the signal for the Gini to go down to a level comparable to the uncorrected published statistics (40 instead of a published 40.3). Such level of measurement error is highly unlikely. Bound et al., 2001, give much lower orders of magnitude for measurement error in income, closer to $20 \%$, and this is the range considered by Chesher and Schluter, 2002 in their application to Indonesian data. Hence, it is unlikely that measurement error explains the high observed inequality in the PSF survey. In addition, given ESPS data is as likely to be error-ridden as PSF, measurement errors certainly cannot account for the difference in the inequality estimates.

In the case of the PSF survey, because consumption data are collected at the cell level, measurement error will take place at that level. In such a case, working at the household level would help to average out some of this noise, while it would be maximal when working at the cell level. That would suffice to induce some intra-household inequality even if the true distribution is egalitarian. Although we already know, thanks to the analysis of section 3.2, that this within-household inequality is not pure noise, as it correlates with a number of observable characteristics of the households, it is important to evaluate the sensitivity of our estimates to measurement error at the cell level. We will again resort to simulations. Assuming measurement error takes the form of a white noise, the idea is to assess how large it should be to explain the whole of the observed share of intra-household inequality.

\footnotetext{
${ }^{22}$ Error to signal variances ratio is given by $v=\frac{\operatorname{Var}(\log Z)}{\operatorname{Var}(\log X)}$, where $\mathrm{Z}$ is the error contaminated measure of consumption and $\mathrm{X}$ the error-free measure of consumption.
} 
Appendix F details the procedure. To summarize, under the assumption that there is no intrahousehold inequality, but that cell consumption is measured with error, we simulate the observed distribution of per capita cell consumption, varying the magnitude of measurement error as a proportion of the variance of the original distribution of log consumption. We then assess the level of error that is needed to reproduce the observed amount of intra-household inequality. Results are shown in appendix table F.1. It appears that it requires an error term with a variance fixed at $70 \%$ of the variance of the original distribution of log-consumption for the decomposition of the Theil index to indicate a within-household share of total inequality of $14 \%$. At $40 \%$, the Gini index for the distribution of per capita cell consumption is $2.75 \%$ higher than the one for the per capita household consumption, as we actually observe in our data (2.56\%). In both cases, such levels of measurement error are unrealistically large compared to the $20 \%$ benchmark mentioned above, so that we are confident measurement error is not the only force driving our results.

\subsection{OTHER ROBUSTNESS CHECKS}

Individual consumption can be measured per capita or per adult equivalent. The use of per capita consumption to assess the extent of inequality is likely to yield a higher level of inequality than the use of per adult equivalent consumption, if there is a positive correlation between the risk of poverty and the number of children in a household. This is true between households, and also within households and between cells, if poor cells have more children than non-poor ones. Hence, using an equivalence scale may provide a different picture on inequality. In Appendix Table C1, we compute the same inequality measures as those presented in Table 2, this time based on consumption per adult equivalent, where a weight of 1 is given to adults, and children between 0 and 14 are weighted 0.5 . As can be seen from this table, the difference with per capita estimates is in line with what was expected: inequality based on per adult equivalent consumption is indeed found lower. But the difference is not 
very high, and the gap between household and cell consumption estimates remains of the same order of magnitude as that of Table 2. As for intra-household inequality, appendix Table C2 shows the inequality decomposition obtained when using per adult equivalent consumption with three different equivalence scales: Scale A is the same as that employed in Table C1, while Scale B puts a reduced weight on very young children (0.2 for children less than age 4). Scale $\mathrm{C}$ applies different weights depending on the kind of commodities. For food, weights are chosen in order to hold account of estimated caloric needs for moderately active people, depending on age and gender, and based on tables provided by the U.S. Department of Health and Human Services. ${ }^{23}$ Results are hardly impacted by the reduced weight given to children: intra-household inequality still accounts for about $13 \%$ of the total (or $43 \%$ of the maximal intra-household inequality simulated taking these equivalence scales into account). Finally, so as to ensure that the results are not driven by education expenditures, an important child specific spending unevenly distributed in the population, we replicate the exercise on consumption aggregates net of education expenditures (school fees, furniture, and transportation). Results are shown in the bottom part of Appendix Table C2. They are not significantly altered. ${ }^{24}$

Poverty measures are likely to be more sensitive to the choice of equivalence scale, if the risk of poverty depends on household or cell size. In table C3 we repeat the same exercise as in table C2 this time for FGT indices. As we can see the estimated poverty rates are a bit higher when scale $C$ is used due to the higher weight given to children between 5 and 14 in the equivalence scale for food consumption, but the gap between FGT indices based on per adult equivalent cell and household consumption persists.

\footnotetext{
${ }^{23}$ https://health.gov/dietaryguidelines/2015/guidelines/appendix-2/

${ }^{24}$ Note that health expenditures are not included in the consumption aggregate we are using.
} 


\section{CONCLUSION}

This paper uses a novel survey designed to measure intra-household consumption inequalities. Gaining a thorough understanding of these issues is all the more crucial that a number of new redistributive public policies are developed today, such as the Programme National de Bourses de Sécurité Familiale, PNBSF, a large conditional cash transfer scheme meant as the stepping stone of a broader social safety net. Whether and how the choice of the beneficiary within the household matters is a central question for the design of such program.

This new survey allows us not only to reevaluate the level of inter-personal inequality in Senegal and to reveal the extent of intra-household inequality, but also to analyze how this leads to a reassessment of the poverty diagnostic for the country.

The consumption survey we designed innovates by collecting information at the level of subgroups within the household, using different respondents for different household cells. A first consequence of this approach is that it allowed us to collect more complete consumption data. Total consumption is measured to be higher than what was obtained with a classical consumption survey at the same period, as well as more unequally distributed. This could have an a priori ambiguous impact on global poverty assessment, since the two effects--one on the mean and one on inequality--should impact poverty estimates in opposite directions. In the context studied here, these two contrary effects seem to compensate each other so that the overall bias is rather small. Now, inequality is shown to be much higher than what was previously thought, with a Gini coefficient reaching 47.1\%, while international statistical yearbooks give a Gini of 40.3 . 
Our results suggest that the more complex the household structure, the bigger the household size, and the more inequality is likely to be underestimated when computed using standard consumption surveys. This would imply that cross-country comparisons of inequality levels should take into account these differences in family structure and organisation.

Within-household inequality accounts for nearly 14\% of inter-personal inequality in Senegal, which we evaluate to be $42 \%$ of the level that would be reached if household heads captured the entire private consumption in households. One of the consequences of such unequal repartition of resources within households is the potential existence of "invisible poor" in households classified as non-poor. Taking intra-household unequal access to resources into account, we assess that as many as $13.4 \%$ of the poor individuals live in non-poor households. They are therefore ignored when the poverty status of the household is supposed to apply uniformly to all household members. This could have important consequences for the effectiveness of anti-poverty policies.

When households are large and of a complex structure, as in Senegal and in many subSaharan African countries, where several somewhat autonomous budgetary units cohabit, it is not the case that everyone has access to the same level of resources. In these contexts, coming as close as possible to the individual when measuring welfare is crucial in order to obtain adequate measures of poverty and help anti-poverty policies to efficiently target the poor. 


\section{REFERENCES}

Agence Nationale de la Statistique et de la Démographie (ANSD) (2007) Enquête de suivi de la pauvreté au Sénégal, ESPS 2005-2006, rapport national, août

Agence Nationale de la Statistique et de la Démographie (ANSD) (2013), Rapport définitif de la deuxième Enquête de Suivi de la Pauvreté au Sénégal (ESPS II), rapport national.

Araar Abdelkrim and Jean-Yves Duclos (2007), "DASP: Distributive Analysis Stata Package", PEP, World Bank, UNDP and Université Laval.

Baland, Jean-Marie, Catherine Guirkinger, and Charlotte Mali (2011),. "Pretending to Be Poor: Borrowing to Escape Forced Solidarity in Cameroon." Economic Development and Cultural Change 60, no. 1 (2011): 1-16.

Baland, Jean-Marie and Roberta Ziparo (2018), "Intra-household bargaining in poor countries", in Anderson Siwan, Lori Beaman and Jean-Philippe Platteau (eds) Towards Gender Equity in Development, Oxford University Press

Bargain Olivier, Guy Lacroix, and Luca Tiberti (2018), "Validating the Collective Model of Household Consumption Using Direct Evidence on Sharing" IZA Discussion Paper No. 11653:

Beck, Simon, Philippe De Vreyer, Sylvie Lambert, Karine Marazyan and Abla Safir (2015), «Child fostering in Senegal », The Journal of Comparative Family Studies, vol 46: 57-73

Beegle Kathleen, De Weerdt Joachim, Friedman Jed and John Gibson (2012), "Methods of household consumption measurement through surveys: Experimental results from Tanzania", Journal of Development Economics, vol. 98(1), May 2012, pp 3-18.

Beegle, Kathleen, Luc Christiaensen, Andrew Dabalen and Isis Gaddis (2016). Poverty in a Rising Africa. Washington, DC: World Bank. (C) World Bank.

https://openknowledge.worldbank.org/handle/10986/22575 License: CC BY 3.0 IGO.

Biewen, Martin (2002), "Bootstrap inference for inequality, mobility and poverty measurement”, Journal of Econometrics, vol. 108, pp.317-342.

Boltz Marie, Karine Marazyan and Paola Villar (2019), " ncome hiding and informal redistribution: A lab-in-the-field experiment in Senegal », Journal of Development Economics, vol. 137 pp 78-92

Bound John, Charles Brown and Nancy Mathiowetz (2001), "Measurement Error in Survey Data" in J.J. Heckman and E. Leamer eds., Handbook of Econometrics, Volume 5, Chapter 59, pp.3705-3843

Brown, Caitlin and Calvi, Rossella and Penglase, Jacob (2019), "Sharing the Pie:

Undernutrition, Intra-Household Allocation, and Poverty", mimeo. 
Brown Caitlin, Martin Ravallion and Dominique van de Walle (Forthcoming), "Most of Africa's Nutritionally-Deprived Women and Children are Not Found in Poor Households", The Review of Economics and Statistics, https://doi.org/10.1162/rest a 00800

Case Anne, Christina Paxson and Joseph Ableidinger (2004), "Orphans in Africa: Parental death, poverty, and school enrollment", Demography 41.3, pp. 483-508.

Chesher Andrew and Christian Schluter (2002), "Welfare Measurement and Measurement Error", Review of Economic Studies, vol. 69, April 2002, pp 357-378

Chiappori, Pierre-Andre, (1988). "Rational Household Labor Supply," Econometrica, Econometric Society, vol. 56(1), 63-90, January

Cogneau Denis, Bossuroy Thomas, De Vreyer Philippe, Guenard Charlotte, Hiller Victor, Leite Philippe, Mesple-Somps Sandrine, Pasquier-Doumer Laure, and Constance Torelli (2006), «Inégalités et équité en Afrique », DIAL WP 2006-11.

Datt, Gautav and Martin Ravallion (1992), "Growth and redistribution components of changes in poverty measures: A decomposition with applications to Brazil ans India in the 1980s", Journal of Development Economics, vol. 38(2), April 1992, pp 275-295.

Deaton, Angus (2005). "Measuring Poverty in a Growing World (or Measuring Growth in a Poor World)," The Review of Economics and Statistics, MIT Press, vol. 87(1), pages 1-19, 04

Deaton, Angus, (1997), The analysis of household surveys : a microeconometric approach to development policy. Washington, D.C. : The World Bank.

Deaton, Angus and Margaret Grosh (2000), “Consumption”, in Grosh, Margaret, Glewwe, Paul (Eds.), Designing Household Survey Questionnaires for Developing Countries: Lessons from 15 Years of the Living Standards Measurement Study. World Bank, Washington, D.C.

Dercon, Stefan, and Krishnan Pramila (2000), "In Sickness and in Health: Risk Sharing within Households in Rural Ethiopia." Journal of Political Economy 108, no. 4 (2000): 688-727.

De Vreyer, Philippe, Sylvie Lambert, Momar Sylla and Abla Safir (2008), "Pauvreté et Structure Familiale. Pourquoi une nouvelle enquête ?", Statéco, n¹02, pp. 5-20.

De Vreyer, Philippe and Björn Nilsson (2019), "When Solidarity Fails: Heterogeneous Effects on Children from Adult Deaths in Senegalese Households", World Development, vol.114, pp.73-94 https://doi.org/10.1016/j.worlddev.2018.09.018

DiNardo, John, Nicole M. Fortin and Thomas Lemieux (1996), "Labor Market Institutions and the Distribution of Wages, 1973-1992: A Semiparametric Approach", Econometrica, vol. 64(5), pp. 1001-1044.

Dunbar, Geoffrey R., Arthur Lewbel and Krishna Pendakur. (2013),. "Children's Resources in Collective Households: Identification, Estimation, and an Application to Child Poverty in Malawi." American Economic Review, 103(1): 438-71. 
D'Souza, Anna and Sharad Tandon (Forthcoming). "Intra-household Nutritional Inequalities in Rural Bangladesh." Economic Development and Cultural Change.

Green, William H. (2000), Econometric Analysis, fourth edition, Prentice Hall.

Haddad, Lawrence, John Hoddinott and Harold Alderman (eds) (1997), Intrahousehold Resource Allocation in Developing Countries, Johns Hopkins University Press, for the International Food Policy Research Institute.

Kakwani, Nanak (1993), Statistical inference in the measurement of poverty, Review of Economics and Statistics, vol. 75, pp.632-639.

Klasen, Stephan and Rahul Lahoti (2016), “How Serious is the Neglect of Intra-Household Inequality in Multi-dimensional Poverty Indices”, CRC-PEG Discussion Papers No. 200.

Lanjouw, Peter (2005), "Constructing a Consumption Aggregate for the Purpose of Welfare Analysis: Issues and Recommendations Concerning the POF 2002/3 in Brazil". Development Economics Research Group, World Bank. Mimeo.

Ndiaye, Salif, Mohamed Ayad (2006), "Enquête Démographique et de Santé. Sénégal 2005", Ministère de la Santé et de la Prévention Médicale. Centre de Recherche pour le Développement Humain. Dakar.

Ndoye, Djibril, Franck Adoho, Prospère Backiny-Yetna, Mariama Fall, Papa Thiecouta Ndiaye, Quentin Wodon (2009), "Tendance et profil de la pauvreté au Sénégal de 1994 à 2006," Perspective Afrique, Association Africaine pour les Sciences sociales, vol. 4(1-3), pages 129.

Nichols, Austin (2008), "Erratum and discussion of propensity-score reweighting", Stata Journal, 8, nº , pp.532-539.

Ravallion, Martin, (2000). "Should Poverty Measures Be Anchored to the National Accounts?" Economic and Political Weekly, 35(35/36), 3245-3252.

Rose, Elaina (1999), "Consumption Smoothing and Excess Female Mortality in Rural India", Review of Economics and Statistics, 81:1, 41-49

Scott, Chris and Ben Amenuvegbe (1991), "Effects of Recall Duration on Reporting of Household Expenditures: an Experimental Study in Ghana", Social Dimensions of Adjustment (SDA) in sub - Saharan Africa working paper; no. 6. Surveys and statistics. Washington, DC : The World Bank.

Van de Walle, Etienne and Aliou Gaye (2006): "Household structure, polygyny and ethnicity in Senegambia: a comparison of census methodologies", in Etienne van de Walle, ed. : African Households : censuses and Surveys. New York, M. E. Sharpe Inc.

World Bank (2015), World Development Report 2016: Equity and Development, World development report. Washington, DC : World Bank Group, Oxford University Press 
Xu, Kuan (2007), U-statistics and their asymptotic results for some inequality and poverty measures, Econometric Reviews, vol. 26, n5, pp.567-577.

Ziparo Roberta (2014) : "Why do spouses communicate? Love or interest? A model and some evidence from Cameroon", JMP 


\section{Appendix A: ESPS/PSF comparison}

\section{Questionnaire design}

The PSF and ESPS surveys differ in their way of measuring consumption by several aspects. PSF innovates in the fact that the consumption questionnaire is addressed to all household members that potentially have a say about resources allocation (the so-called "cell heads"), as opposed to the usual practice in which only one member (commonly the household head) is sought to answer that part of the questionnaire. In doing so, and since the head may not be informed of the consumption of all members, the PSF survey should capture more consumption than regular surveys, particularly in large extended households where several adults may have their own income sources. However, there are other variations in the questionnaires that may explain eventual discrepancies in the level of consumption captured by the two surveys: the degree of commodity detail and the length of the reference period are two obvious differences that have been investigated in the literature (see Beegle $e t$ al. 2012 for a survey). It seems common sense to assume that the higher the number of items over which consumption is collected, the larger should be the total level of consumption in the household. However the gain in coverage warranted by a longer list of items may come at the cost of a loss in reporting precision, due to household or surveyor fatigue resulting from an exceedingly long questionnaire. Nevertheless, there is a large consensus in the literature on the fact that a short list of commodity items results in a less precise and lower aggregate consumption level. Conclusions concerning the recall period are less clear cut. On the one hand long recall periods may be better able to capture the consumption of commodities that are not frequently bought over the year and limit the risk of "telescoping" errors, in which respondent include consumptions just outside the reference period. On the other hand, the longer the recall period, the more are respondent likely to under-report consumption due to recollection difficulties. Evidence concerning the impact of the reference period length is mixed, with some papers invoking a too short report period to explain a level of consumption lower than expected (Lanjouw 2005 for food consumption in Brazil) and other showing that the level of daily consumption expenditure decreases with the number of days of recall (Scott and Amenuvegbe 1990 for Ghana), while Deaton and Grosh (2000) using data from LSMS surveys conducted in Côte d'Ivoire, Vietnam and Pakistan conclude that measured consumption does not depend much on the recall period length. Based on experimental data from Tanzania, Beegle et al. (2012) compare eight different questionnaire designs. They find that the "usual" consumption approach in which the household is asked to report the level of consumption over a regular month and the number of months of consumption, yields rather unprecise results when compared to a 7 days record period: food consumption is underestimated and non-food consumption overestimated. They attribute these discrepancies to the high cognitive demand of the usual food questions which require the respondent to make an estimation of their consumption rather than just to recall and count what has been consumed over a given period. They advocate that the 7 days recall period may get closer to the true consumption level, though it may perform poorly in households with a large number of adults. 
Table A1.1 : Comparison of ESPS and PSF surveys designs

\begin{tabular}{|c|c|c|c|c|c|c|}
\hline & \multicolumn{3}{|c|}{ ESPS } & \multicolumn{3}{|c|}{ PSF } \\
\hline & Respondent & Number and list of items & Recall period & Respondent & Number and list of items & Recall period \\
\hline $\begin{array}{l}\text { Purchased food } \\
\text { (every day } \\
\text { spending) }\end{array}$ & \multicolumn{3}{|c|}{ Every day spending is not separately covered. } & $\begin{array}{l}\text { Household } \\
\text { members in } \\
\text { charge of } \\
\text { preparing } \\
\text { meals }\end{array}$ & $\begin{array}{l}\text { Respondent is asked about } \\
\text { the amount of every day } \\
\text { spending ("dépense } \\
\text { quotidienne", DQ), she/he } \\
\text { receives from contributors. }\end{array}$ & $\begin{array}{l}\text { Respondent is } \\
\text { asked about the } \\
\text { length of the } \\
\text { period covered by } \\
\text { the DQ (from one } \\
\text { day to three } \\
\text { months). }\end{array}$ \\
\hline $\begin{array}{l}\text { Food } \\
\text { contributions } \\
\text { received in kind }\end{array}$ & \multicolumn{3}{|c|}{$\begin{array}{l}\text { Contributions received in } \\
\text { kind are not covered. }\end{array}$} & $\begin{array}{l}\text { Household } \\
\text { head }\end{array}$ & $\begin{array}{l}\text { Respondent is asked about } \\
\text { the amount of the } \\
\text { contributions received by } \\
\text { the household on a regular } \\
\text { basis. }\end{array}$ & $\begin{array}{l}\text { Frequency is } \\
\text { reported by the } \\
\text { respondent who } \\
\text { can choose among } \\
\text { twelve modalities } \\
\text { from every day to } \\
\text { every year. } \\
\text { Respondent is } \\
\text { asked about the } \\
\text { usual } \\
\text { contributions. }\end{array}$ \\
\hline $\begin{array}{l}\text { Other purchased } \\
\text { food }\end{array}$ & $\begin{array}{l}\text { Household } \\
\text { head }\end{array}$ & $\begin{array}{l}\text { Respondent is asked about } \\
\text { expenditure on } 27 \text { items: } \\
\text { Millet, maize, sorghum and } \\
\text { fonio; Sub-products from } \\
\text { millet, maize and sorghum; } \\
\text { Rice; Peanuts and their } \\
\text { subproducts; Vegetable } \\
\text { (olive, cotton, sesame) and } \\
\text { peanut oil; Other oils }\end{array}$ & $\begin{array}{l}\text { Over the } 30 \text { last } \\
\text { days. The } \\
\text { respondent is then } \\
\text { asked about the } \\
\text { number of times it } \\
\text { spent the same } \\
\text { amount over the } \\
12 \text { last months. }\end{array}$ & $\begin{array}{l}\text { Household } \\
\text { head }\end{array}$ & $\begin{array}{l}\text { The head of household is } \\
\text { asked about items that } \\
\text { he/she is in charge of } \\
\text { buying him/herself (this } \\
\text { does not necessarily means } \\
\text { that he/she pays for it and } \\
\text { the act of purchasing may } \\
\text { be delegated). A total of } 25 \\
\text { food items are }\end{array}$ & $\begin{array}{l}\text { Frequency is } \\
\text { reported by the } \\
\text { respondent who } \\
\text { can choose among } \\
\text { twelve modalities } \\
\text { from every day to } \\
\text { every year. } \\
\text { Respondent is }\end{array}$ \\
\hline
\end{tabular}




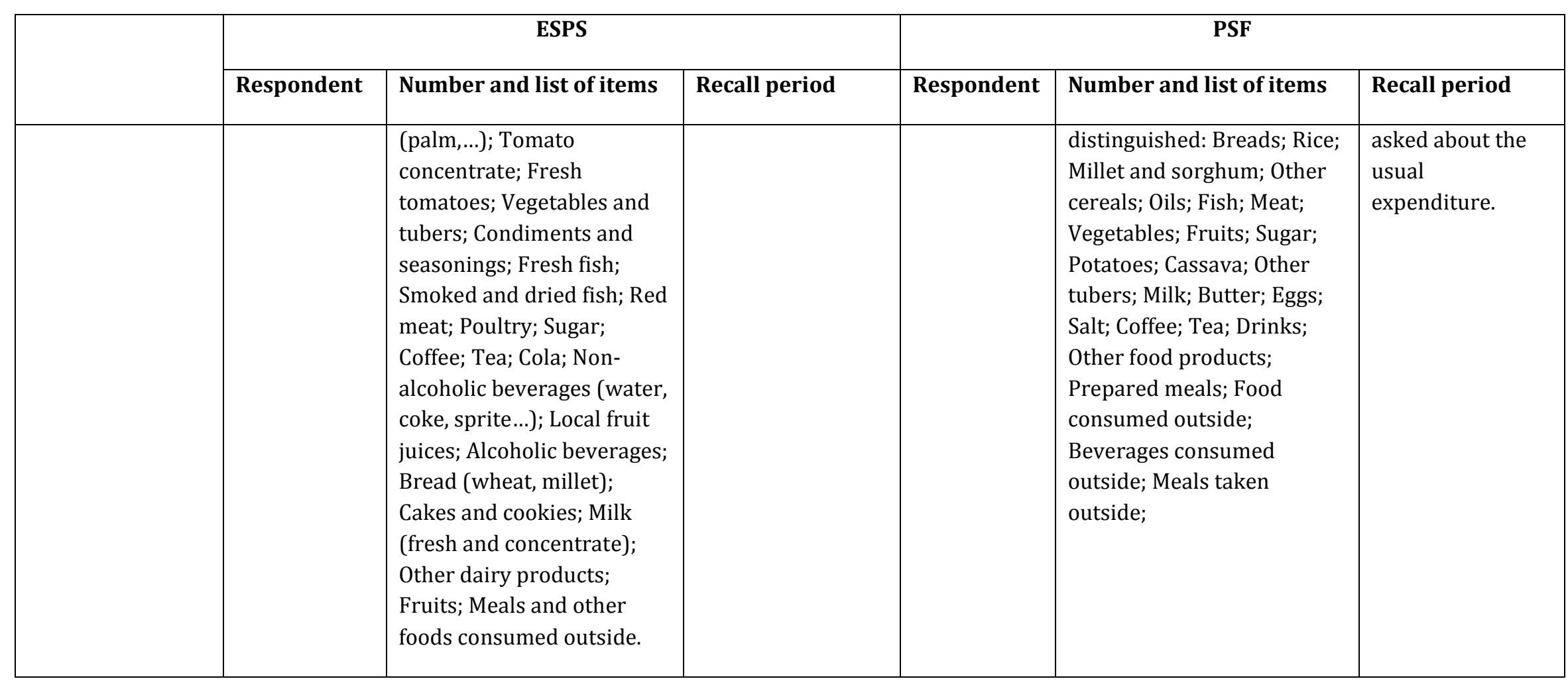




\begin{tabular}{|c|c|c|c|c|c|c|}
\hline & \multicolumn{3}{|c|}{ ESPS } & \multicolumn{3}{|c|}{ PSF } \\
\hline & Respondent & Number and list of items & Recall period & Respondent & Number and list of items & Recall period \\
\hline $\begin{array}{l}\text { Home produced } \\
\text { food }\end{array}$ & $\begin{array}{l}\text { Household } \\
\text { head }\end{array}$ & $\begin{array}{l}3 \text { categories: Agricultural } \\
\text { products; Livestock } \\
\text { products; Fishing products. }\end{array}$ & $\begin{array}{l}\text { Over the } 12 \text { last } \\
\text { months. }\end{array}$ & $\begin{array}{l}\text { Household } \\
\text { head }\end{array}$ & $\begin{array}{l}3 \text { categories: Agricultural } \\
\text { products; Livestock } \\
\text { products; Fishing products. }\end{array}$ & $\begin{array}{l}\text { Over the last } 12 \\
\text { months. } \\
\text { For each item } \\
\text { they produce, } \\
\text { hunt, fish or } \\
\text { gather: } \\
\text { Respondent } \\
\text { asked how many } \\
\text { months in the } \\
\text { year it is } \\
\text { consumed and the } \\
\text { monthly market } \\
\text { value }\end{array}$ \\
\hline Utilities & $\begin{array}{l}\text { Household } \\
\text { head }\end{array}$ & $\begin{array}{l}3 \text { items: Water; Electricity; } \\
\text { Telephone (fixed and } \\
\text { mobile). }\end{array}$ & $\begin{array}{l}\text { Over the two last } \\
\text { months. }\end{array}$ & $\begin{array}{l}\text { Household } \\
\text { and cell } \\
\text { heads }\end{array}$ & $\begin{array}{l}4 \text { items: Water; Electricity; } \\
\text { Fixed telephone; Mobile } \\
\text { phone. }\end{array}$ & $\begin{array}{l}\text { Frequency is } \\
\text { reported by the } \\
\text { respondent who }\end{array}$ \\
\hline $\begin{array}{l}\text { Housing fuels } \\
\text { and combustible } \\
\text { materials }\end{array}$ & $\begin{array}{l}\text { Household } \\
\text { head }\end{array}$ & $\begin{array}{l}4 \text { items: Gas; Charcoal; } \\
\text { Wood; Combustible } \\
\text { materials (candles and } \\
\text { petroleum). }\end{array}$ & $\begin{array}{l}\text { Over the last } 30 \\
\text { days (and if not } \\
\text { purchased, amount } \\
\text { usually spent over } \\
\text { a month). }\end{array}$ & $\begin{array}{l}\text { Household } \\
\text { and cell } \\
\text { heads }\end{array}$ & $\begin{array}{l}1 \text { item: Fuels and } \\
\text { combustible materials } \\
\text { (wood, charcoal, gas, } \\
\text { candles and petroleum); }\end{array}$ & $\begin{array}{l}\text { can choose among } \\
\text { twelve modalities } \\
\text { from every day to } \\
\text { every year. } \\
\text { Respondent is }\end{array}$ \\
\hline Durable goods & $\begin{array}{l}\text { Household } \\
\text { head }\end{array}$ & $\begin{array}{l}3 \text { items: Furniture and } \\
\text { electrical appliances; } \\
\text { Transport means (car, }\end{array}$ & $\begin{array}{l}\text { Over the last } 12 \\
\text { months }\end{array}$ & $\begin{array}{l}\text { Household } \\
\text { and cell } \\
\text { heads }\end{array}$ & $\begin{array}{l}2 \text { items: Furniture and } \\
\text { electrical appliances; } \\
\text { Transport means (car, }\end{array}$ & $\begin{array}{l}\text { asked about both } \\
\text { usual expenditure } \\
\text { and last }\end{array}$ \\
\hline
\end{tabular}




\begin{tabular}{|c|c|c|c|c|c|c|}
\hline & \multicolumn{3}{|c|}{ ESPS } & \multicolumn{3}{|c|}{ PSF } \\
\hline & Respondent & Number and list of items & Recall period & Respondent & Number and list of items & Recall period \\
\hline & & $\begin{array}{l}\text { motorcycle, bicycle...); } \\
\text { Jewelries. }^{25}\end{array}$ & & & motorcycle, bicycle...) & expenditure. \\
\hline $\begin{array}{l}\text { Other non- } \\
\text { personal items }\end{array}$ & $\begin{array}{l}\text { Household } \\
\text { head }\end{array}$ & $\begin{array}{l}6 \text { items: Soap and housing } \\
\text { cleaning products; Maid; } \\
\text { Housing maintenance and } \\
\text { repair; Small appliances } \\
\text { and cutlery; Motor fuels, } \\
\text { repair of transport means; } \\
\text { Other expenses. }\end{array}$ & $\begin{array}{l}\text { Over the last } 30 \\
\text { days (and if not } \\
\text { purchased, amount } \\
\text { usually spent over } \\
\text { a month). }\end{array}$ & $\begin{array}{l}\text { Household } \\
\text { and cell } \\
\text { heads }\end{array}$ & $\begin{array}{l}7 \text { items: Maid; Housing } \\
\text { maintenance and repair; } \\
\text { Furniture and electrical } \\
\text { appliances repair; Small } \\
\text { appliances and cutlery; } \\
\text { Motor fuels, repair of } \\
\text { transport means; } \\
\text { Recreational devices and } \\
\text { accessories; Other goods } \\
\text { and services. }\end{array}$ & \\
\hline Education & $\begin{array}{l}\text { Household } \\
\text { head }\end{array}$ & $\begin{array}{l}5 \text { items: School fees; Books } \\
\text { and school supplies; School } \\
\text { transportation; School } \\
\text { uniform; Other expenses. }\end{array}$ & $\begin{array}{l}\text { Over the last } \\
\text { school year }\end{array}$ & Cell heads & $\begin{array}{l}5 \text { items: School fees; Books } \\
\text { and school supplies; School } \\
\text { transportation; Private } \\
\text { lessons; Vocational training. }\end{array}$ & $\begin{array}{l}\text { Frequency is } \\
\text { reported by the } \\
\text { respondent who } \\
\text { can choose among } \\
\text { twelve modalities }\end{array}$ \\
\hline Personal items & $\begin{array}{l}\text { Household } \\
\text { head }\end{array}$ & $\begin{array}{l}8 \text { items: Soaps; Perfumes } \\
\text { and cosmetics; Tobacco } \\
\text { and cigarettes; } \\
\text { Recreational services, } \\
\text { books and newspapers; } \\
\text { Clothing; Shoes; Cloth; } \\
\text { Tailoring. }\end{array}$ & $\begin{array}{l}\text { Over the last } 30 \\
\text { days (and if not } \\
\text { purchased, amount } \\
\text { usually spent over } \\
\text { a month). }\end{array}$ & Cell heads & $\begin{array}{l}6 \text { items: Transport; Clothing } \\
\text { and shoes; Personal care } \\
\text { (soaps, perfumes and } \\
\text { cosmetics, tobacco and } \\
\text { cigarettes etc.); Personal } \\
\text { belongings (jewelries etc.); } \\
\text { Recreational services; } \\
\text { Books and newspapers. }\end{array}$ & $\begin{array}{l}\text { from every day to } \\
\text { every year. } \\
\text { Respondent is } \\
\text { asked about both } \\
\text { usual expenditure } \\
\text { and last } \\
\text { expenditure. }\end{array}$ \\
\hline
\end{tabular}

${ }^{25}$ In the PSF survey, jewelry expenditures are covered in the personal item section of the questionnaire. 
In table A1.1 we report the main features of the ESPS and PSF consumption questionnaires. In both surveys the list of commodities is restricted to what has been included in the consumption aggregates computed for this paper. The PSF survey sample is small compared to that of the ESPS (1762 households versus 13559). For this reason, and since in Senegal the large majority of households are owners of their housing (more than $80 \%$ at the time of the survey, and more than 97\% in rural areas), the PSF survey does not allow to compute imputed rents for owners in rural areas. Therefore, we decided not to include housing rents in our expenditure aggregates. Also excluded are income and direct taxes, together with gifts, construction, celebration that are not completely covered in PSF. We also exclude health expenditures, since we wish to exclude them from the analysis as interpersonal differences are likely to largely correspond to difference in needs. The PSF and ESPS surveys do not differ much in the level of disaggregation of the commodities included by the consumption questionnaire: 30 food and 29 non-food items are covered by ESPS, versus 28 food and 25 non-food in PSF. There are two major differences in the way food expenses are collected. First, while in ESPS the design of the food consumption questionnaire does not differ from that of non-food, in PSF the food section is first addressed to household members in charge of preparing meals. The respondents are asked about the amount of the daily expenditure ("dépense quotidienne", DQ) that is spent for these meals. Field interviews that have been conducted before the survey showed that the DQ mainly covers expenses for fresh food, such as vegetables, fruits, fish and meat. Other food commodities, such as rice or oil for instance, are often bought directly by the head of the household, generally in bulks. The second part of the questionnaire covers these expenses. Later, cell heads are also asked to report any expenditure related to food and meals consumed outside the household by members of their cell. In ESPS, this question is addressed only to the household head. The second important difference lies in the fact that the PSF questionnaire records the amount of contributions in kind received by the head of the household. This is an important feature since about $20 \%$ of the households declare they receive such contributions.

The second important difference between ESPS and PSF designs is that while ESPS varies the length of recall with the type of commodities, PSF gives the respondent the choice of the reference period.

Finally, it should also be mentioned that, aside the consumption survey, the PSF questionnaire is much longer than that of ESPS. Since consumption is covered after the individual surveys, the quality of the consumption data in PSF may be negatively impacted in large households due to respondent and surveyor fatigue. Note, nonetheless, that the extra length of the questionnaire is somewhat compensated in terms of fatigue in PSF by the fact that the burden of the survey is shared among all cell heads.

\section{Implications for consumption measurement}

Overall, it is difficult to assess how these differences between designs may impact the measurement of consumption. As mentioned, interviewing several adult members of the household is likely to allow PSF to reduce mismeasurement due to asymmetric information within the household. Food consumption may also be better captured in PSF, since respondent in charge of preparing meals and of buying food on markets generally know precisely how much they spend every day, or every week, and this amount is unlikely to change much on a short period of time. On the contrary, household and surveyor fatigue, being potentially more likely to happen in PSF may impact negatively the measurement of consumption. As for variations in the length of the reference 
period it is difficult to anticipate how they correlate with any discrepancy between ESPS and PSF total household consumption aggregates.

Nevertheless, two conjectures can be made. First, if the PSF design is better able to apprehend food consumption than that of ESPS and if household or surveyor fatigue does not impact too much the ability to capture consumption of food commodities, then one can expect to find a higher level of food consumption in the PSF survey. Moreover, since in more than $80 \%$ of households all members take their meals together, the gap between surveys should not depend on the household structure. Second, for total household consumption, one cannot conjecture whether any difference should be observed on average between surveys, but we may expect the ratio of PSF to ESPS household consumption for a given household type to increase with the complexity of the household structure.

Testing these conjectures is not straightforward. Contrary to PSF, the ESPS survey has not been designed to capture the entire complexity of Senegalese households. One can only rely on the usual "relationship to head" question to recover, in as much as possible, the household structure and identify the number of budget decision units. The basic strategy is to count the number of household members of the different types, as defined by their relationship to the head: spouse, child, grand-child, parent, grand-parent, brother/sister, nephew/niece, other parent, unrelated etc. and then to compare that number to the household size. For instance, a simple two cell household can be constituted of a male head, his (unique) spouse and his children. The children can be those of the spouse, in which case they belong to her cell, or they can be born from another marriage, in which case they belong to the head's cell. In any case, households with the head, one spouse and children and with no other members are two cell households. The difficulty is that these nuclear families are not the only kind of two cell households, but they are the only ones that ESPS can identify for sure. For instance, consider a household in which on top of the household head, his spouse and their children, one also finds the head's sister and his niece. This could be a two cells or a three cells household, depending on the relationship between these two extra members. If the niece of the household head is also the daughter of his sister, then the two constitute a third cell, while if they are not related, both will be in the head's cell. To sum up, we are able to identify four kinds of households in the ESPS sample (and of course also in the PSF): (1) single person households, (2) one cell households, (3) more than one cell households with only "nuclear" family members and their offspring (head, spouse(s), children, grand-children), (4) other households. For reasons just explained, some truly one cell households may be misclassified as "other" households, but the opposite cannot happen.

We apply this classification rule to both the PSF and ESPS samples and compare the estimated average household per capita food and total consumption for each category of households and for the entire samples. In order to make meaningful comparisons, we need to account for any sampling frame variation and for the fact that about one year separates the ESPS and PSF surveys. Simple unweighted comparison of surveyed household locations shows that PSF oversampled the Dakar region compared to ESPS (37.5\% in PSF versus 11.8\% in ESPS). Since households in Dakar are on average wealthier than those in other regions of the country, a simple comparison of average consumption levels is unlikely to reflect solely differences in survey design. Using the survey weights helps to correct imbalances but not completely. The weighted proportion of households in Dakar is still 3\% higher in PSF than in ESPS (29.5\% for PSF versus 26.6\% for ESPS) and very large imbalances appear between the Matam (PSF: 12.8\%; ESPS: 3.4\%) and Thies (PSF: $6.4 \%$; 
ESPS: $14.2 \%)$ regions. In the face of this, we decided to follow a strategy initiated by DiNardo, Fortin and Lemieux (1996) ${ }^{26}$. Pooling together the PSF and ESPS data, we estimated a logit model on the probability of being in the PSF sample, using region and urbanization dummies as explanatory variables, since these variables have been used to stratify the sampling frame. Estimation results are then used to compute the predicted probability of belonging to the PSF sample, ps. Then ESPS observations are reweighted using ps/(1-ps) as weights. This strategy gives much better results in that all strong imbalances between samples are corrected, with the maximum difference between the two surveys in the proportion of households living in a given region being lower than $0.5 \%$. We also hold account of the general progression of prices between the two surveys, using figures provided by the Senegalese statistical agency (ANSD). PSF has been conducted between November 2006 and April 2007, almost exactly a year after ESPS. In order to estimate the average change of the price index between these two periods, we computed the mean of the annual inflation rates calculated over the 6 twelve-month periods going from November 2005 to November 2006, December 2005 to December 2006, January 2006 to January 2007, February 2006 to February 2007, March 2006 to March 2007, and April 2006 to April 2007. For total consumption, this leads to an average one year inflation rate of $4.7 \%$. ESPS figures have been adjusted accordingly. ${ }^{27,28}$

Tables A2.1 and A2.2 show the estimated levels of average aggregate food and total household consumption per capita for all four categories of households and for the entire sample. The pattern is clear and consistent with our intuitions. In table A2.1, the results show no apparent relationship between household complexity and the difference between the two surveys estimates. However, as we conjectured, the amount of measured food consumption is always found higher in PSF, though the difference is not always significant. Table A2.2 shows the same exercise, but this time for total consumption. For single person households we find a higher level of annual expenditure in favour of PSF, but the difference is not significant. For other kinds of households, as expected we see a clear increase in the difference between estimated average aggregate levels of consumption per capita when moving from one cell households (with a negative nonsignificant difference) to "other" complex households, for which PSF expenditure per capita are significantly higher than ESPS. The last line of the table shows the values of expenditure per capita when we hold account of household size, or in other words when the unit of observation is the individual and not the

\footnotetext{
${ }^{26}$ See Nichols (2008).

${ }^{27}$ A total of 1781 households are included in the original PSF sample. Three households have been dropped due to completely incoherent expenditure records. Three others have been excluded due to their head sharing his time between several households, which raised doubt on the correct allocation of his declared expenditure. One household was dropped due to incoherent recording of members' relationship with the head and another five households, because though they include two cells, the surveyor recorded all expenditure in the head's cell. Finally, seven households could not be included due to missing information on some key variable. We end up with a total sample size of 1762 households kept in the analysis.
}

${ }^{28}$ PSF Households with exceedingly high levels of expenditures have been screened and, when possible, their records corrected case-by-case based on information provided by other variables in the survey. No such work could be done on the ESPS data since the available information is more limited. The maximum level of annual expenditure per capita in PSF is found around 5,810,000 CFA (that is about $\$ 11,500$ in 2006-2007). In ESPS the maximum amount is around 13,780,000 CFA $(\$ 27,300)$, but only eight households out of 13559 have values higher than the PSF maximum. We kept these observations in the sample as very wealthy households are more likely to be included in ESPS than PSF, due to the much larger sample size. 
household. On average, the level of expenditure per capita is found higher in PSF than in ESPS by about $15 \% .^{29}$

\footnotetext{
${ }^{29}$ The average household size is found lower in PSF than in ESPS: 7.96 members versus 9.11. This results from a higher proportion of one cell households in PSF (13.9\% versus 10.6\% in ESPS) and could impact the comparison if larger households have on average a lower level of consumption per capita. In order to control for this possible source of bias, we run the same comparisons using household structure and household size as extra covariates in the logit regression used to build propensity score weights. Doing this, we can compare expenditure levels between households which on average share the same location, structure and size. This does not have a large impact on the estimates.
} 
Table A2.1: average value of household food consumption per capita by household structure - all food commodities

\begin{tabular}{lccc}
\hline & $\begin{array}{c}\text { PSF survey } \\
\text { Mean } \\
\text { Household type }\end{array}$ & $\begin{array}{c}\text { ESPS survey } \\
\text { Mean } \\
(\mathrm{N})\end{array}$ & $\begin{array}{c}\text { Difference } \\
\text { PSF-ESPS } \\
\text { (Std. err.) }\end{array}$ \\
\hline Single person households & 570,530 & 502,432 & 68,098 \\
& $(98)$ & $(540)$ & $(38,759)$ \\
Other one cell households & 289,300 & 262,873 & 26,427 \\
& $(147)$ & $(901)$ & $(16,621)$ \\
More than one cell 'nuclear' hh. & 217,181 & 193,024 & 24,156 \\
& $(549)$ & $(3,971)$ & $(17,379)$ \\
Other households & 181,343 & 150,434 & 30,909 \\
& $(968)$ & $(8,147)$ & $(5,321)$ \\
All households & 223,162 & 181,548 & 41,614 \\
& $(1,762)$ & $(13,559)$ & $(6,746)$ \\
\hline \multicolumn{2}{l}{ Source: PSF and ESPS surveys, authors' calculations. In the first two columns, the sample size is } \\
reported between parentheses. In the third column, the standard error of the difference is \\
reported.
\end{tabular}

Table A2.2: average value of household total consumption per capita by household structure - all commodities

\begin{tabular}{lccc}
\hline & $\begin{array}{c}\text { PSF survey } \\
\text { Mean }\end{array}$ & $\begin{array}{c}\text { ESPS survey } \\
\text { Mean } \\
(\mathrm{N})\end{array}$ & $\begin{array}{c}\text { Difference } \\
\text { PSF-ESPS } \\
\text { (Std. err.) }\end{array}$ \\
\hline Single person households & $1,086,946$ & $1,000,344$ & 86,602 \\
& $(98)$ & $(540)$ & $(84,672)$ \\
Other one cell households & 531,182 & 535,947 & $-4,764$ \\
& $(147)$ & $(901)$ & $(52,169)$ \\
More than one cell 'nuclear' hh. & 392,651 & 351,172 & 41,479 \\
& $(549)$ & $(3,971)$ & $(22,022)$ \\
Other households & 367,697 & 301,915 & 65,783 \\
& $(968)$ & $(8,147)$ & $(14,561)$ \\
All households & 429,115 & 371,231 & 57,884 \\
& $(1,762)$ & $(13,559)$ & $(12,859)$ \\
All individuals & 328,135 & 284,917 & 43,218 \\
& $(13,988)$ & $(123,486)$ & $(3,519)$ \\
\hline Source: PSF and ESPS surveys, authors' calculations. In the first two columns, the sample size is \\
reported between parentheses. In the third column, the standard error of the difference is \\
reported.
\end{tabular}

\section{Poverty and inequality}

We now compare the values of poverty and inequality indices obtained with the two surveys. Two poverty lines are considered. The lowest, «nutrition », line corresponds to the level of expenditure necessary to purchase enough food to attain a minimum caloric intake of 2400 kcal per adult equivalent and per day. Since in PSF we do not have a reliable set of price data, we use the poverty lines computed by Ndoye et al. (2009), that we update using the average inflation rate between the ESPS and PSF surveys. The second line corresponds to the satisfaction of individual basic needs. It is computed using the average non-food per adult equivalent expenditure of households for which food consumption per adult equivalent is between 0.95 and 1.05 the nutrition poverty line. This 
average is added to the nutrition threshold to obtain the basic needs line. Table A3.1 reports the values of the poverty thresholds for Dakar, other towns and rural areas. ${ }^{30}$

Table A3.1: Nutrition and basic needs poverty lines

\begin{tabular}{lcc}
\hline & Nutrition poverty line & Basic needs poverty line \\
\hline Dakar & 396 & 835 \\
Other towns & 369 & 647 \\
Rural areas & 356 & 558 \\
\hline \multicolumn{2}{c}{ Source: PSF survey, authors' calculations. Values are given in CFA francs. }
\end{tabular}

Using these thresholds, we can compute FGT indexes for both the PSF and ESPS surveys. The results are reported in table A3.2. Not much difference is found between the values of the FGT indexes. PSF finds more people under the nutrition threshold (16.7\% versus $12.5 \%)$, but less under the basic needs one ( $42.8 \%$ versus $45 \%)$.

Table A3.2: FGT indexes for PSF and ESPS surveys

\begin{tabular}{lcccc}
\hline & \multicolumn{2}{c}{ Nutrition poverty line } & \multicolumn{2}{c}{ Basic needs poverty line } \\
Index & PSF & ESPS & PSF & ESPS \\
\hline Poverty headcount & 0.167 & 0.125 & 0.428 & 0.450 \\
Mean poverty gap & 0.042 & 0.027 & 0.143 & 0.130 \\
Mean squared poverty gap & 0.016 & 0.009 & 0.064 & 0.052 \\
\hline \multicolumn{2}{l}{ Source: PSF and ESPS surveys, authors' calculations based on 13988 and 123486 individual observations } \\
for PSF and ESPS surveys respectively & \multicolumn{4}{c}{}
\end{tabular}

Looking now at inequality, we computed the Gini index for both surveys. Here the two surveys lead to widely different measures of the extent of inequalities between individual levels of consumption per capita in Senegal: while, according to ESPS, inequality appears relatively low, with a Gini equal to 38.9, PSF finds it at a much higher level (Gini=47.1). These results are confirmed by figure A1 in which we plot kernel density estimates of PSF and ESPS distributions of log-consumption per capita. The graph shows that compared to ESPS, distribution in PSF is skewed towards the right and high values of consumption per capita. This is not surprising given that addressing the consumption questionnaire to more than one adult in the household is more likely to lead to higher values of consumption in relatively wealthy households.

30 We repeated the same exercise on the ESPS sample. The resulting basic needs thresholds are at bit lower than those of PSF (507, 592 and 780 CFA per adult equivalent and per day for rural areas, other towns and Dakar respectively). 
Figure A.1: ESPS and PSF densities for household per capita expenditure

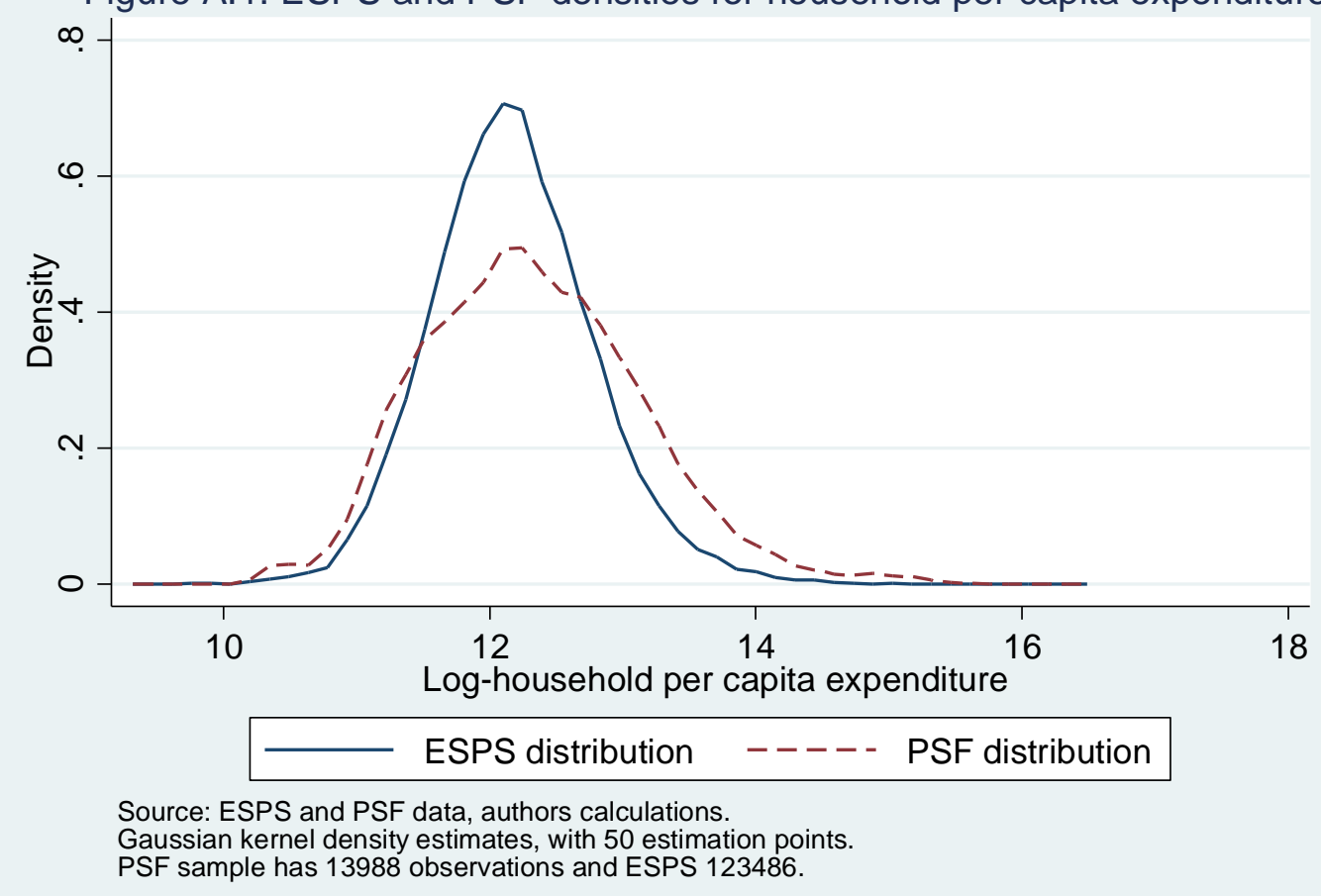

\section{Appendix B: Differences between poverty and inequality measures}

The rationale for using bootstrap to evaluate the significance of differences between poverty and inequality indices is provided by Biewen (2002). Asymptotic normality of the interdecile, interquartile, mean logarithmic deviation, and Theil indices can be established using the deltamethod (Green, 2000). Kakwani (1993) provides the same results for the headcount poverty and the poverty gap indices. For the Gini index, see Xu (2007). In this Appendix, we reproduce in Tables B1 and B2 the estimated differences between inequality indices, based on per capita consumption, and between poverty indices, based on per adult equivalent consumption. Similar results for inequality indices based on per adult equivalent consumption are available upon request but not shown.

Table B1: Differences between inequality indices from Table 3

\begin{tabular}{llllll}
\hline & Gini & $90 / 10$ & $75 / 25$ & $\begin{array}{l}\text { Mean log } \\
\text { dev }\end{array}$ & Theil-T \\
\hline All consumption & $2.56^{* * *}$ & $1.02^{* * *}$ & 0.10 & $0.05^{* * *}$ & $0.07^{* * *}$ \\
& $(0.21)$ & $(0.23)$ & $(0.07)$ & $(0.00)$ & $(0.01)$ \\
Non-food consumption & $4.44^{* * *}$ & $6.91^{* * *}$ & $0.68^{* * *}$ & $0.15^{* * *}$ & $0.18^{* * *}$ \\
& $(0.33)$ & $(1.00)$ & $(0.21)$ & $(0.01)$ & $(0.02)$ \\
Food consumption & $1.22^{* * *}$ & $0.55^{* * *}$ & $0.10^{* *}$ & $0.02^{* * *}$ & $0.02^{* * *}$ \\
& $(0.13)$ & $(0.13)$ & $(0.04)$ & $(0.00)$ & $(0.00)$ \\
\hline
\end{tabular}

Sources: PSF survey, $\mathrm{N}=1762$, authors' calculations. Bootstrap standard errors (250 replications). ${ }^{* * *}, * * *$ : significant at the $10 \%, \%$, 
1\% level.

Table B2: Differences between poverty indices from table 8

\begin{tabular}{|c|c|c|c|c|}
\hline & \multicolumn{2}{|c|}{ Nutrition poverty line } & \multicolumn{2}{|c|}{ Basic needs poverty line } \\
\hline & $\begin{array}{l}\text { Headcount } \\
\text { index }\end{array}$ & $\begin{array}{l}\text { Poverty gap } \\
\text { index }\end{array}$ & $\begin{array}{l}\text { Headcount } \\
\text { index }\end{array}$ & $\begin{array}{l}\text { Poverty gap } \\
\text { index }\end{array}$ \\
\hline National & $\begin{array}{l}1.56^{* * * *} \\
(0.45)\end{array}$ & $\begin{array}{l}0.88^{* * * *} \\
(0.12)\end{array}$ & $\begin{array}{l}3.51 * * * \\
(0.64)\end{array}$ & $\begin{array}{l}1.78^{* * * *} \\
(0.15)\end{array}$ \\
\hline Dakar & $\begin{array}{c}0.29 \\
(0.39)\end{array}$ & $\begin{array}{l}0.16^{* * *} \\
(0.06)\end{array}$ & $\begin{array}{l}3.56^{* * *} \\
(1.14)\end{array}$ & $\begin{array}{l}1.63^{* * *} \\
(0.22)\end{array}$ \\
\hline Other urban areas & $\begin{array}{l}2.07 * * \\
(1.01)\end{array}$ & $\begin{array}{l}0.95 * * * \\
(0.31)\end{array}$ & $\begin{array}{l}3.43^{* * *} \\
(1.26)\end{array}$ & $\begin{array}{l}1.62 * * * \\
(0.30)\end{array}$ \\
\hline Rural areas & $\begin{array}{l}2.19 * * * \\
(0.81)\end{array}$ & $\begin{array}{l}1.34 * * * \\
(0.20)\end{array}$ & $\begin{array}{l}3.51 \text { *** } \\
(0.99)\end{array}$ & $\begin{array}{l}1.95^{* * *} \\
(0.24)\end{array}$ \\
\hline
\end{tabular}

Source: PSF survey, authors' calculations. N=1762 households and 4293 cells. Bootstrap standard errors (250 replications) between parentheses. ${ }^{*}, * *, * * *$ : significant at the $10 \%, 5 \%, 1 \%$ level. 
Appendix C: inequality measures, using per adult equivalent consumption.

Table C1: Inequality measures, on per adult equivalent consumption.

\begin{tabular}{|c|c|c|c|c|c|}
\hline & Gini & $90 / 10$ & $75 / 25$ & $\begin{array}{l}\text { Mean log } \\
\text { dev }\end{array}$ & Theil-T \\
\hline \multicolumn{6}{|l|}{$\begin{array}{l}\text { Per capita household } \\
\text { consumption }\end{array}$} \\
\hline Total consumption & $\begin{array}{l}45.28 \\
(1.10)\end{array}$ & $\begin{array}{l}7.14 \\
(0.35)\end{array}$ & $\begin{array}{l}2.84 \\
(0.09)\end{array}$ & $\begin{array}{l}0.35 \\
(0.02)\end{array}$ & $\begin{array}{l}0.40 \\
(0.03)\end{array}$ \\
\hline Non-food consumption & $\begin{array}{l}61.55 \\
(1.29)\end{array}$ & $\begin{array}{l}17.91 \\
(0.90)\end{array}$ & $\begin{array}{l}4.99 \\
(0.24)\end{array}$ & $\begin{array}{l}0.73 \\
(0.03)\end{array}$ & $\begin{array}{l}0.79 \\
(0.05)\end{array}$ \\
\hline Food consumption & $\begin{array}{l}37.36 \\
(0.70)\end{array}$ & $\begin{array}{l}5.52 \\
(0.25)\end{array}$ & $\begin{array}{l}2.31 \\
(0.06)\end{array}$ & $\begin{array}{l}0.23 \\
(0.01)\end{array}$ & $\begin{array}{l}0.24 \\
(0.01)\end{array}$ \\
\hline \multicolumn{6}{|c|}{ Per capita cell consumption } \\
\hline Total consumption & $\begin{array}{l}47.25^{* * *} \\
(1.05)\end{array}$ & $\begin{array}{l}7.90 * * * \\
(0.39)\end{array}$ & $\begin{array}{l}2.86 \\
(0.08)\end{array}$ & $\begin{array}{l}0.38^{* * *} \\
(0.02)\end{array}$ & $\begin{array}{l}0.45^{* * *} \\
(0.03)\end{array}$ \\
\hline Non-food consumption & $\begin{array}{l}65.32^{* * *} \\
(1.15)\end{array}$ & $\begin{array}{l}22.97 * * * \\
(1.59)\end{array}$ & $\begin{array}{l}5.47^{* *} \\
(0.24)\end{array}$ & $\begin{array}{l}0.85^{* * *} \\
(0.03)\end{array}$ & $\begin{array}{l}0.94 * * * \\
(0.05)\end{array}$ \\
\hline Food consumption & $\begin{array}{l}38.41^{* * *} \\
(0.68)\end{array}$ & $\begin{array}{l}5.88 * * * \\
(0.26)\end{array}$ & $\begin{array}{l}2.39 * * \\
(0.07)\end{array}$ & $\begin{array}{l}0.25 * * * \\
(0.01)\end{array}$ & $\begin{array}{l}0.26 * * * \\
(0.01)\end{array}$ \\
\hline
\end{tabular}


Table C2: Inequality decomposition, per adult equivalent consumption

\begin{tabular}{|c|c|c|c|}
\hline & $\begin{array}{c}\text { Theil } \\
\text { within }\end{array}$ & $\begin{array}{c}\text { Theil } \\
\text { between }\end{array}$ & Share within \\
\hline \multicolumn{4}{|l|}{ Scale A } \\
\hline Total consumption & $\begin{array}{c}0.06 \\
(0.01)\end{array}$ & $\begin{array}{c}0.39 \\
(0.03)\end{array}$ & $\begin{array}{l}12.30 \\
(1.36)\end{array}$ \\
\hline Non-food consumption & $\begin{array}{c}0.15 \\
(0.01)\end{array}$ & $\begin{array}{c}0.79 \\
(0.05)\end{array}$ & $\begin{array}{l}15.89 \\
(1.69)\end{array}$ \\
\hline Food consumption & $\begin{array}{c}0.01 \\
(0.00)\end{array}$ & $\begin{array}{c}0.24 \\
(0.01)\end{array}$ & $\begin{array}{c}5.66 \\
(0.67)\end{array}$ \\
\hline \multicolumn{4}{|l|}{ Scale B } \\
\hline Total consumption & $\begin{array}{c}0.05 \\
(0.01)\end{array}$ & $\begin{array}{c}0.38 \\
(0.03)\end{array}$ & $\begin{array}{l}11.99 \\
(1.34)\end{array}$ \\
\hline Non-food consumption & $\begin{array}{c}0.14 \\
(0.01)\end{array}$ & $\begin{array}{c}0.77 \\
(0.05)\end{array}$ & $\begin{array}{l}15.67 \\
(1.67)\end{array}$ \\
\hline Food consumption & $\begin{array}{c}0.01 \\
(0.00)\end{array}$ & $\begin{array}{c}0.24 \\
(0.01)\end{array}$ & $\begin{array}{c}5.39 \\
(0.63) \\
\end{array}$ \\
\hline \multicolumn{4}{|l|}{ Scale C } \\
\hline Total consumption & $\begin{array}{c}0.06 \\
(0.01)\end{array}$ & $\begin{array}{c}0.40 \\
(0.03)\end{array}$ & $\begin{array}{l}12.14 \\
(1.32)\end{array}$ \\
\hline Non-food consumption & $\begin{array}{c}0.15 \\
(0.01)\end{array}$ & $\begin{array}{c}0.79 \\
(0.05)\end{array}$ & $\begin{array}{l}15.89 \\
(1.69)\end{array}$ \\
\hline Food consumption & $\begin{array}{c}0.01 \\
(0.00)\end{array}$ & $\begin{array}{c}0.26 \\
(0.01)\end{array}$ & $\begin{array}{c}5.50 \\
(0.65)\end{array}$ \\
\hline \multicolumn{4}{|c|}{$\begin{array}{l}\text { Scale A - without education } \\
\text { expenditure }\end{array}$} \\
\hline Total consumption & $\begin{array}{c}0.06 \\
(0.01)\end{array}$ & $\begin{array}{c}0.39 \\
(0.03)\end{array}$ & $\begin{array}{l}12.97 \\
(1.37)\end{array}$ \\
\hline Non-food consumption & $\begin{array}{c}0.16 \\
(0.02)\end{array}$ & $\begin{array}{c}0.80 \\
(0.05)\end{array}$ & $\begin{array}{l}16.97 \\
(1.64)\end{array}$ \\
\hline $\begin{array}{l}\text { Source: PSF survey, autho } \\
\text { standard errors ( } 250 \text { replica } \\
\text { Scale B: adult: } 1 \text { : child } 5 \text { to } \\
0.83 \text {; boy } 5 \text { to } 14 \text { : } 0.77 \text {; gir } \\
\text { weights for non-food consur }\end{array}$ & $\begin{array}{l}\mathrm{N}=1763 \\
\text { parenthese } \\
0 \text { to } 4: 0 . \\
\text { child } 0 \text { to }\end{array}$ & $\begin{array}{l}\text { Ads and } 42 \\
C \text { : male ad } 1 \\
\text { for food } c\end{array}$ & $\begin{array}{l}\text { Bootstrap } \\
\text { to } 14: 0.5 \\
\text { emale adult: } \\
\text { ion; scale A }\end{array}$ \\
\hline
\end{tabular}

Table C3: Sensitivity of FGT indices to equivalence scales

\begin{tabular}{|c|c|c|c|c|c|c|}
\hline & \multicolumn{3}{|c|}{ Nutrition poverty line } & \multicolumn{3}{|c|}{ Basic needs poverty line } \\
\hline Scale & Headcount & $\begin{array}{l}\text { Poverty } \\
\text { gap }\end{array}$ & $\begin{array}{c}\text { Squared } \\
\text { poverty gap }\end{array}$ & Headcount & Poverty gap & $\begin{array}{c}\text { Squared } \\
\text { poverty gap }\end{array}$ \\
\hline \multicolumn{7}{|c|}{$\begin{array}{l}\text { Household per adult equivalent } \\
\text { consumption }\end{array}$} \\
\hline Scale A & 0.167 & 0.042 & 0.016 & 0.428 & 0.143 & 0.064 \\
\hline Scale B & 0.145 & 0.035 & 0.012 & 0.390 & 0.125 & 0.054 \\
\hline Scale C & 0.183 & 0.046 & 0.017 & 0.435 & 0.148 & 0.068 \\
\hline \multicolumn{7}{|c|}{ Cell per adult equivalent consumption } \\
\hline Scale A & 0.182 & 0.051 & 0.020 & 0.463 & 0.160 & 0.075 \\
\hline Scale B & 0.159 & 0.043 & 0.016 & 0.430 & 0.140 & 0.063 \\
\hline Scale C & 0.196 & 0.055 & 0.022 & 0.469 & 0.167 & 0.079 \\
\hline
\end{tabular}




\section{Appendix D: Sensitivity of poverty comparison estimates to the choice of poverty line}

Figures D.1a to D.1c below show the estimated difference between the poverty rates obtained with the cell and household consumption per adult equivalent depending on the position of the poverty line. ${ }^{31}$ As we can see, the difference between poverty rates is significant for a large range of poverty lines.

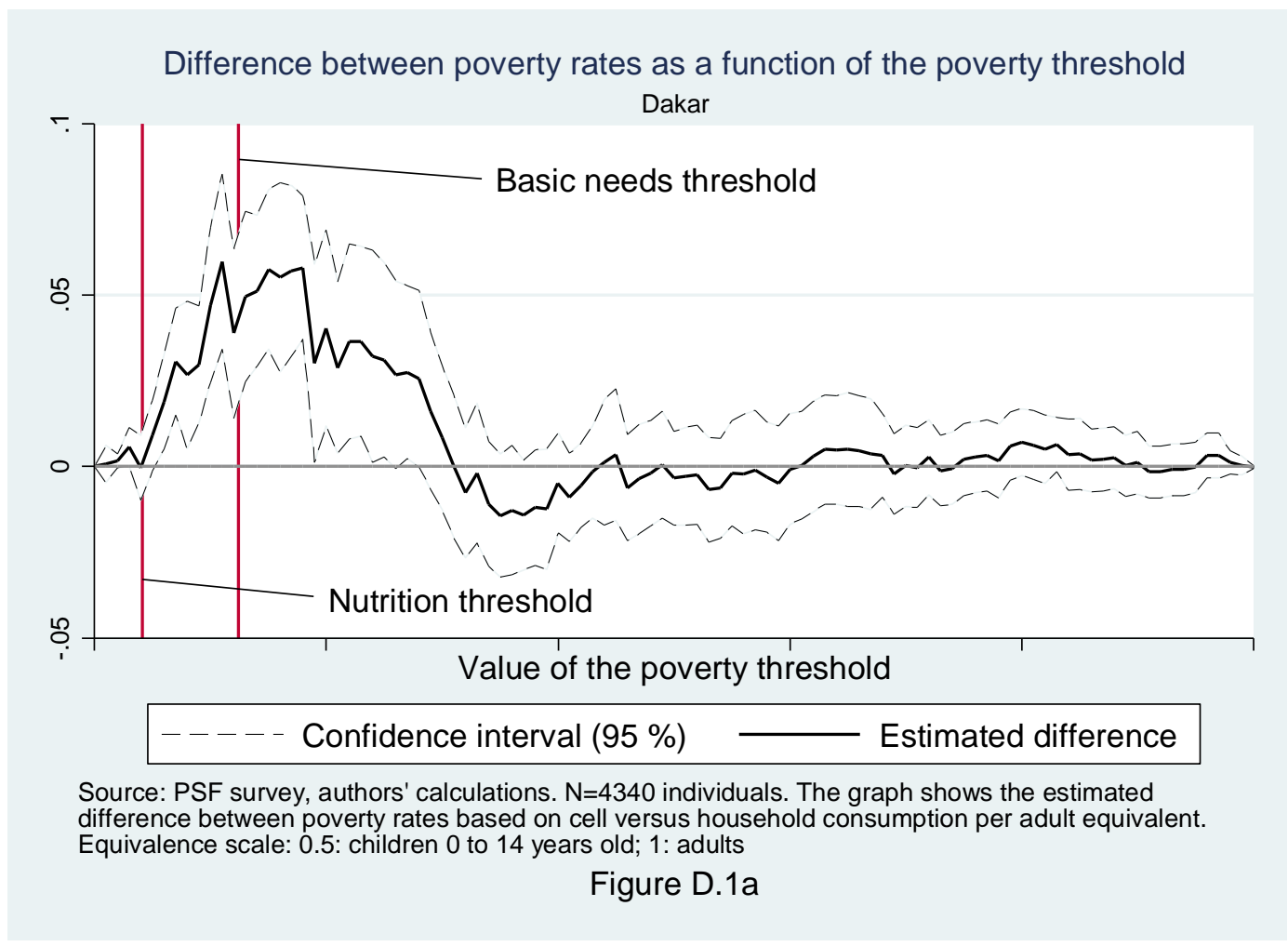

31 Graphs have been drawn using Stata command cfgts2d from the DASP Package and available on line at http://dasp.ecn.ulaval.ca/ (Araar and Duclos, 2007). 
Difference between poverty rates as a function of the poverty threshold

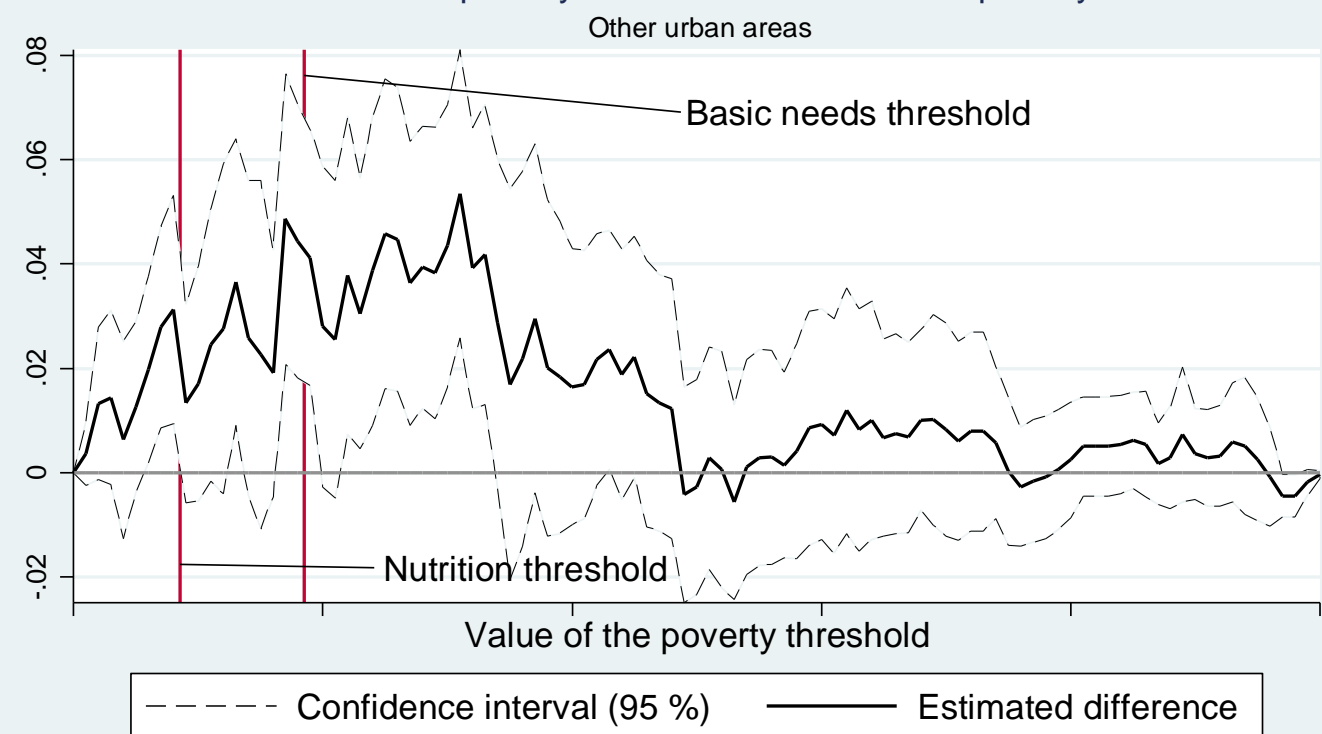

Source: PSF survey, authors' calculations. $\mathrm{N}=2716$ individuals. The graph shows the estimated difference between poverty rates based on cell versus household consumption per adult equivalent. Equivalence scale: 0.5: children 0 to 14 years old; 1 : adults.

Figure D.1b

Difference between poverty rates as a function of the poverty threshold

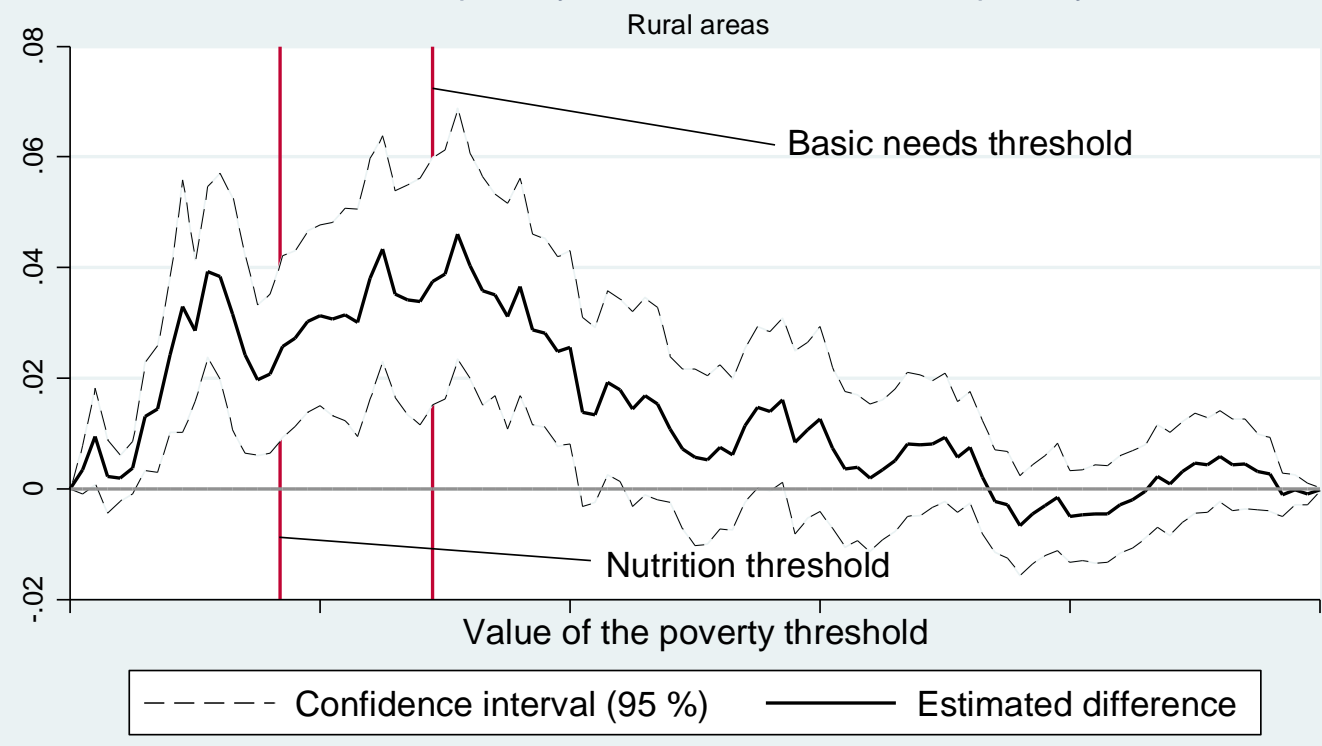

Source: PSF survey, authors' calculations. $\mathrm{N}=6440$ individuals. The graph shows the estimated difference between poverty rates based on cell versus household consumption per adult equivalent. Equivalence scale: 0.5 : children 0 to 14 years old; 1 : adults.

\section{Figure D.1c}


Appendix E: Additional results.

Appendix E1: Correlates of within household inequality, consumption deciles.

\begin{tabular}{|c|c|c|c|}
\hline VARIABLES & $\begin{array}{c}(1) \\
\text { Theil within }\end{array}$ & $\begin{array}{c}\text { (2) } \\
\text { Theil within -food }\end{array}$ & $\begin{array}{c}\text { (3) } \\
\text { Theil within }- \text { nonfood }\end{array}$ \\
\hline Dakar & $\begin{array}{l}-0.0163 \\
(0.0120)\end{array}$ & $\begin{array}{c}0.00299 \\
(0.00749)\end{array}$ & $\begin{array}{c}-0.105^{* * *} \\
(0.0215)\end{array}$ \\
\hline Other urban areas & $\begin{array}{l}-0.00801 \\
(0.0102)\end{array}$ & $\begin{array}{c}0.00341 \\
(0.00536)\end{array}$ & $\begin{array}{c}-0.0680^{* * *} \\
(0.0199)\end{array}$ \\
\hline o.decile_cons 1 & - & - & - \\
\hline decile_cons 2 & $\begin{array}{l}0.0331 * * * \\
(0.00996)\end{array}$ & $\begin{array}{c}0.0150 \\
(0.00971)\end{array}$ & $\begin{array}{c}0.0582 * * \\
(0.0273)\end{array}$ \\
\hline decile_cons 3 & $\begin{array}{c}0.0117 \\
(0.00814)\end{array}$ & $\begin{array}{l}-0.00884 \\
(0.00552)\end{array}$ & $\begin{array}{c}0.0797 * * * \\
(0.0263)\end{array}$ \\
\hline decile_cons 4 & $\begin{array}{l}0.0160 * * \\
(0.00730)\end{array}$ & $\begin{array}{l}-0.00184 \\
(0.00607)\end{array}$ & $\begin{array}{l}0.0513 * * \\
(0.0254)\end{array}$ \\
\hline decile_cons 5 & $\begin{array}{l}0.0312 * * * \\
(0.00918)\end{array}$ & $\begin{array}{c}0.00501 \\
(0.00880)\end{array}$ & $\begin{array}{c}0.0964 * * * \\
(0.0282)\end{array}$ \\
\hline decile_cons 6 & $\begin{array}{l}0.0378 * * * \\
(0.00998)\end{array}$ & $\begin{array}{c}0.00435 \\
(0.00666)\end{array}$ & $\begin{array}{c}0.0855^{* * * *} \\
(0.0276)\end{array}$ \\
\hline decile_cons 7 & $\begin{array}{l}0.0444^{* * *} \\
(0.00972)\end{array}$ & $\begin{array}{l}-0.00148 \\
(0.00772)\end{array}$ & $\begin{array}{l}0.110 * * * \\
(0.0261)\end{array}$ \\
\hline decile_cons 8 & $\begin{array}{c}0.0565 * * * \\
(0.0124)\end{array}$ & $\begin{array}{l}0.000743 \\
(0.00909)\end{array}$ & $\begin{array}{l}0.115^{* * *} \\
(0.0257)\end{array}$ \\
\hline decile_cons 9 & $\begin{array}{c}0.0837^{* * *} \\
(0.0163)\end{array}$ & $\begin{array}{l}-0.00596 \\
(0.00641)\end{array}$ & $\begin{array}{l}0.180^{* * *} \\
(0.0302)\end{array}$ \\
\hline decile_cons 10 & $\begin{array}{c}0.0888 * * * \\
(0.0226)\end{array}$ & $\begin{array}{c}-0.0116 \\
(0.00774)\end{array}$ & $\begin{array}{l}0.148 * * * \\
(0.0362)\end{array}$ \\
\hline Household size & $\begin{array}{l}-0.000567 \\
(0.00171)\end{array}$ & $\begin{array}{c}0.00124 \\
(0.00143)\end{array}$ & $\begin{array}{l}-0.00320 \\
(0.00317)\end{array}$ \\
\hline $\mathrm{Nb}$ of cells in the hh & $\begin{array}{l}0.000173 \\
(0.00550)\end{array}$ & $\begin{array}{c}0.00389 \\
(0.00243)\end{array}$ & $\begin{array}{c}0.000964 \\
(0.0125)\end{array}$ \\
\hline $\mathrm{Nb}$ of children $0-4$ y.o & $\begin{array}{c}0.00438 \\
(0.00324)\end{array}$ & $\begin{array}{l}-0.00117 \\
(0.00265)\end{array}$ & $\begin{array}{l}0.0144 * * \\
(0.00666)\end{array}$ \\
\hline $\mathrm{Nb}$ of children $5-14$ y.o & $\begin{array}{l}0.00570^{* *} \\
(0.00269)\end{array}$ & $\begin{array}{l}-0.00192 \\
(0.00191)\end{array}$ & $\begin{array}{l}0.0172 * * * \\
(0.00581)\end{array}$ \\
\hline $\mathrm{Nb}$ of women $15-65$ y.o. & $\begin{array}{l}-0.00326 \\
(0.00315)\end{array}$ & $\begin{array}{c}-0.00466 * * \\
(0.00192)\end{array}$ & $\begin{array}{l}-0.00253 \\
(0.00616)\end{array}$ \\
\hline $\mathrm{Nb}$ of elderly $66+\mathrm{y} . \mathrm{o}$ & $\begin{array}{c}0.00400 \\
(0.00628)\end{array}$ & $\begin{array}{l}-0.00124 \\
(0.00332)\end{array}$ & $\begin{array}{l}0.00140 \\
(0.0115)\end{array}$ \\
\hline 2-cell hh, head + other & $\begin{array}{c}-0.0239 * * * \\
(0.00777)\end{array}$ & $\begin{array}{l}-0.000737 \\
(0.00573)\end{array}$ & $\begin{array}{c}-0.0791 * * * \\
(0.0159)\end{array}$ \\
\hline 3+-cell hh: head and wives. & $\begin{array}{l}0.0211^{*} \\
(0.0107)\end{array}$ & $\begin{array}{c}0.00360 \\
(0.00817)\end{array}$ & $\begin{array}{c}0.0616 * * \\
(0.0279)\end{array}$ \\
\hline 3+-cell hh: head, wife(wives), + other & $\begin{array}{l}0.0209 * \\
(0.0110)\end{array}$ & $\begin{array}{l}-0.00306 \\
(0.00417)\end{array}$ & $\begin{array}{c}0.0349 \\
(0.0220)\end{array}$ \\
\hline 3+-cell hh: head + others (no spouse) & $\begin{array}{l}-0.0240 * * \\
(0.00972)\end{array}$ & $\begin{array}{c}-0.0198 * * * \\
(0.00586)\end{array}$ & $\begin{array}{c}-0.0448^{* *} \\
(0.0207)\end{array}$ \\
\hline All meals taken together & $\begin{array}{c}-0.0537 * * * \\
(0.0130)\end{array}$ & $\begin{array}{c}-0.0783 * * * \\
(0.0145)\end{array}$ & $\begin{array}{l}-0.0371 * \\
(0.0201)\end{array}$ \\
\hline Constant & $\begin{array}{c}0.0528 * * * \\
(0.0188)\end{array}$ & $\begin{array}{c}0.0722 * * * \\
(0.0165)\end{array}$ & $\begin{array}{l}0.123 * * * \\
(0.0463)\end{array}$ \\
\hline $\begin{array}{l}\text { Observations } \\
\text { R-squared }\end{array}$ & $\begin{array}{l}1,426 \\
0.105\end{array}$ & $\begin{array}{l}1,426 \\
0.162\end{array}$ & $\begin{array}{l}1,426 \\
0.111\end{array}$ \\
\hline
\end{tabular}

Source: PSF survey, authors' calculations. $\mathrm{N}=1426$ households with at least two cells. OLS regressions. Additional controls: religion and ethnicity of the household head. Reference category for household structure is a household with two cells: head and spouse. 2-cell hh: head + other refers to households composed of 2 cells, where the second cell is not that of the head's spouse. 3+-cell hh: head and wives refers to polygamous households, where all the cells are headed by member of the conjugal unit. 3+-cell hh: head, wife(wives) + other refers to households with at least 3 cells and where at least one of the cells is not headed by a spouse of the head. 3+-cell hh: head+others (no wife) refers to households with more than 3 cells and where none of them is headed by a spouse of the household head. Robust standard errors in parentheses, clustered at the PSU level, *** $\mathrm{p}<0.01$, $* * \mathrm{p}<0.05, * \mathrm{p}<0.1$. 
Table E2: Probability of being a non-poor household with poor members

\begin{tabular}{|c|c|c|c|}
\hline VARIABLES & $\begin{array}{l}\text { (1) } \\
\text { All }\end{array}$ & $\begin{array}{c}\text { (2) } \\
\text { 80\% richest hh - } \\
\text { non-poor }\end{array}$ & $\begin{array}{c}\text { (3) } \\
\text { 20\% poorest hh - } \\
\text { non-poor }\end{array}$ \\
\hline Dakar & $\begin{array}{c}11.71 * * * \\
(4.371)\end{array}$ & $\begin{array}{c}2.221^{* * * *} \\
(0.675)\end{array}$ & \\
\hline Other urban area & $\begin{array}{c}2.496 * * * \\
(0.799)\end{array}$ & $\begin{array}{c}1.620 \\
(0.546)\end{array}$ & $\begin{array}{c}7.814 \\
(11.29)\end{array}$ \\
\hline nb of children 0 - 4 y.o. & $\begin{array}{c}0.873 \\
(0.0950)\end{array}$ & $\begin{array}{c}0.903 \\
(0.0932)\end{array}$ & $\begin{array}{c}0.767 \\
(0.303)\end{array}$ \\
\hline nb of children 5 - 14 y.o. & $\begin{array}{c}1.003 \\
(0.0880)\end{array}$ & $\begin{array}{c}1.147 \\
(0.0995)\end{array}$ & $\begin{array}{c}0.479 * * \\
(0.155)\end{array}$ \\
\hline nb of elderly over 66 y.o. & $\begin{array}{c}0.807 \\
(0.167)\end{array}$ & $\begin{array}{c}0.713 \\
(0.154)\end{array}$ & $\begin{array}{c}1.521 \\
(1.011)\end{array}$ \\
\hline hh head is polygamous & $\begin{array}{c}1.056 \\
(0.278)\end{array}$ & $\begin{array}{c}1.151 \\
(0.308)\end{array}$ & $\begin{array}{c}0.408 \\
(0.325)\end{array}$ \\
\hline Hh size & $\begin{array}{c}1.001 \\
(0.0534)\end{array}$ & $\begin{array}{c}1.020 \\
(0.0501)\end{array}$ & $\begin{array}{c}1.440 \\
(0.337)\end{array}$ \\
\hline hh head has no formal schooling & $\begin{array}{c}1.253 \\
(0.319)\end{array}$ & $\begin{array}{c}2.218^{* * *} \\
(0.560)\end{array}$ & $\begin{array}{c}1.022 \\
(0.797)\end{array}$ \\
\hline $\mathrm{Nb}$ of cells & $\begin{array}{c}1.283 \\
(0.231)\end{array}$ & $\begin{array}{c}1.093 \\
(0.198)\end{array}$ & $\begin{array}{c}2.079 \\
(1.680)\end{array}$ \\
\hline 2-cell hh, head + other & $\begin{array}{c}0.807 \\
(0.329)\end{array}$ & $\begin{array}{c}0.759 \\
(0.338)\end{array}$ & $\begin{array}{c}2.256 \\
(2.563)\end{array}$ \\
\hline 3+-cell hh: head and wives. & $\begin{array}{c}1.700 \\
(0.792)\end{array}$ & $\begin{array}{c}1.133 \\
(0.555)\end{array}$ & $\begin{array}{c}0.749 \\
(0.948)\end{array}$ \\
\hline 3+-cell hh: head, wife(wives), + other & $\begin{array}{c}2.906 * * * \\
(1.004)\end{array}$ & $\begin{array}{c}3.008^{* * *} \\
(1.028)\end{array}$ & $\begin{array}{c}1.193 \\
(1.297)\end{array}$ \\
\hline 3+-cell hh: head + others (no wife) & $\begin{array}{c}1.020 \\
(0.521)\end{array}$ & $\begin{array}{c}0.793 \\
(0.403)\end{array}$ & $\begin{array}{c}0.106 \\
(0.204)\end{array}$ \\
\hline All meals taken together & $\begin{array}{c}0.288^{* * *} \\
(0.0829)\end{array}$ & $\begin{array}{c}0.389 * * * \\
(0.101)\end{array}$ & $\begin{array}{c}0.381 \\
(0.384)\end{array}$ \\
\hline Log hh per adult eq consumption & $\begin{array}{c}0.00551^{* * *} \\
(0.00283)\end{array}$ & & \\
\hline Dakar $=0$, & & & - \\
\hline Constant & $\begin{array}{c}7.12 \mathrm{e}+27 * * * \\
(4.595 \mathrm{e}+28)\end{array}$ & $\begin{array}{c}0.0538 * * * \\
(0.0255)\end{array}$ & $\begin{array}{c}0.204 \\
(0.337)\end{array}$ \\
\hline Observations & 876 & 793 & 83 \\
\hline
\end{tabular}

Source PSF survey, author's calculations. Logit estimates, odd ratios reported; coefficient standard errors in parentheses. ${ }^{* * *} \mathrm{p}<0.01,{ }^{* *} \mathrm{p}<0.05,{ }^{*} \mathrm{p}<0.1$ 
Table E3 Probability that all meals are taken jointly in the household

\begin{tabular}{|c|c|}
\hline VARIABLES & $\begin{array}{c}\text { All meals } \\
\text { shared }\end{array}$ \\
\hline decile_cons1 & $\begin{array}{l}1.925 * \\
(0.753)\end{array}$ \\
\hline decile_cons2 & $\begin{array}{c}1.083 \\
(0.356)\end{array}$ \\
\hline decile_cons3 & $\begin{array}{c}0.868 \\
(0.262)\end{array}$ \\
\hline decile_cons4 & $\begin{array}{c}1.322 \\
(0.422)\end{array}$ \\
\hline decile_cons5 & $\begin{array}{c}0.845 \\
(0.235)\end{array}$ \\
\hline decile_cons6 & $\begin{array}{c}1.012 \\
(0.282)\end{array}$ \\
\hline decile_cons7 & $\begin{array}{c}0.902 \\
(0.235)\end{array}$ \\
\hline decile_cons8 & $\begin{array}{c}0.793 \\
(0.197)\end{array}$ \\
\hline decile_cons9 & $\begin{array}{c}0.855 \\
(0.204)\end{array}$ \\
\hline Dakar & $\begin{array}{c}0.670 * * \\
(0.122)\end{array}$ \\
\hline Other urban area & $\begin{array}{c}0.783 \\
(0.148)\end{array}$ \\
\hline $\mathrm{Nb}$ of cells & $\begin{array}{l}1.312^{* *} \\
(0.144)\end{array}$ \\
\hline $\mathrm{Nb}$ of couples in the household & $\begin{array}{c}0.662^{* * *} \\
(0.0940)\end{array}$ \\
\hline 2-cell hh: head+wife. & $\begin{array}{c}1.708^{* * *} \\
(0.285)\end{array}$ \\
\hline 2-cell hh : head + other & $\begin{array}{l}1.510^{*} \\
(0.367)\end{array}$ \\
\hline 3+-cell hh : head, wife(wives) + other & $\begin{array}{l}1.549 * \\
(0.352)\end{array}$ \\
\hline Hh head is polygamous & $\begin{array}{c}1.074 \\
(0.172)\end{array}$ \\
\hline Nb of children $0-4$ y.o. & $\begin{array}{l}0.870 * * \\
(0.0556)\end{array}$ \\
\hline Nb of children 5 - 14 y.o. & $\begin{array}{c}0.969 \\
(0.0415)\end{array}$ \\
\hline $\mathrm{Nb}$ of women $15-65$ & $\begin{array}{l}0.893^{* *} \\
(0.0452)\end{array}$ \\
\hline Nb of elderly over 66 y.o. & $\begin{array}{c}0.867 \\
(0.111)\end{array}$ \\
\hline Constant & $\begin{array}{c}4.407^{* * *} \\
(1.136)\end{array}$ \\
\hline Observations & 1,762 \\
\hline \multicolumn{2}{|c|}{$\begin{array}{l}\text { Source : PSF survey, authors' calculations. } * * * \mathrm{p}<0.01 \text {, } \\
* * \mathrm{p}<0.05, * \mathrm{p}<0 \text {. Logit estimates. Odd ratios reported. } \\
\text { Coeff. standard errors in parentheses. Top consumption } \\
\text { decile as a reference category. }\end{array}$} \\
\hline
\end{tabular}




\section{Appendix F: Simulating the impact of measurement error on intra-household inequality.}

The exercise is the following. Assume that the true distribution of consumption is such that there is no intra-household inequality. Nevertheless, because of (classical) measurement errors at the cell level, the observed per capita cell consumption differs from the per capita household consumption. We simulate the observed distribution of per capita cell consumption varying the magnitude of the error term, by drawing it from a normal distribution with a variance chosen as a percentage of the variance of the original distribution of log-consumption. This percentage varies from 10 to $80 \%$. From this simulated cell consumption data, we compute again both the per capita household consumption and the per capita cell consumption. We then calculate the Gini and Theil indices of the 2 distributions and assess the variance of the white noise that would be enough to explain a level of intra-household inequality equal to $14.6 \%$ of total inequality. We replicate the simulation 100 times to compute the standard errors of the indices. We will not focus on the total level of inequality, as the addition of such white noise will mechanically increase it.

Table F.1. below gives the result of these simulations. It appears that it requires an error term with a variance fixed at $70 \%$ of the variance of the original distribution of logconsumption for the decomposition of the Theil index to indicate a within-household share of total inequality of $14 \%$. At $40 \%$, the Gini index for the distribution of per capita cell consumption is $2.75 \%$ higher than the one for the per capita household consumption, as we actually observe in our data (2.56\%). In both cases, such levels of measurement error are unrealistically large compared to the $20 \%$ benchmark mentioned above, so that we are confident measurement error is not the only force driving our results. 
Table F.1.: Simulated inequality measures in the presence of measurement error

\begin{tabular}{|c|c|c|c|c|c|}
\hline \multirow[t]{2}{*}{$\sigma^{2}\left(\mathrm{u}_{\mathrm{c}}\right) / \sigma^{2}\left(\ln \mathrm{Y}_{\mathrm{h}}\right)$} & \multirow{2}{*}{$\begin{array}{c}\begin{array}{c}\text { Per capita } \\
\text { household } \\
\text { consumption }\end{array} \\
\text { Gini }\end{array}$} & \multicolumn{4}{|c|}{ Per capita cell consumption } \\
\hline & & Gini & Theil & Theil within & $\begin{array}{c}\text { Share of } \\
\text { within } \\
\text { inequality }\end{array}$ \\
\hline $10 \%$ & $\begin{array}{l}48.83 \\
(0.39)\end{array}$ & $\begin{array}{l}49.61 \\
(0.39)\end{array}$ & $\begin{array}{c}0.50 \\
(0.01)\end{array}$ & $\begin{array}{c}0.01 \\
(0.00)\end{array}$ & 0.03 \\
\hline $20 \%$ & $\begin{array}{l}49.65 \\
(0.52)\end{array}$ & $\begin{array}{l}51.16 \\
(0.50)\end{array}$ & $\begin{array}{c}0.53 \\
(0.02)\end{array}$ & $\begin{array}{c}0.03 \\
(0.00)\end{array}$ & 0.06 \\
\hline $30 \%$ & $\begin{array}{l}50.60 \\
(0.66)\end{array}$ & $\begin{array}{l}52.78 \\
(0.63)\end{array}$ & $\begin{array}{c}0.57 \\
(0.03)\end{array}$ & $\begin{array}{c}0.04 \\
(0.00)\end{array}$ & 0.08 \\
\hline $40 \%$ & $\begin{array}{l}51.37 \\
(0.82)\end{array}$ & $\begin{array}{l}54.12 \\
(0.75)\end{array}$ & $\begin{array}{c}0.60 \\
(0.03)\end{array}$ & $\begin{array}{c}0.06 \\
(0.00)\end{array}$ & 0.10 \\
\hline $50 \%$ & $\begin{array}{l}52.10 \\
(0.79)\end{array}$ & $\begin{array}{l}55.41 \\
(0.73)\end{array}$ & $\begin{array}{c}0.63 \\
(0.03)\end{array}$ & $\begin{array}{c}0.07 \\
(0.00)\end{array}$ & 0.11 \\
\hline $60 \%$ & $\begin{array}{l}52.79 \\
(0.82) \\
\end{array}$ & $\begin{array}{l}56.57 \\
(0.77) \\
\end{array}$ & $\begin{array}{c}0.65 \\
(0.03)\end{array}$ & $\begin{array}{c}0.08 \\
(0.00)\end{array}$ & 0.13 \\
\hline $70 \%$ & $\begin{array}{l}53.61 \\
(0.90)\end{array}$ & $\begin{array}{l}57.86 \\
(0.82) \\
\end{array}$ & $\begin{array}{c}0.69 \\
(0.04) \\
\end{array}$ & $\begin{array}{c}0.10 \\
(0.01)\end{array}$ & 0.14 \\
\hline $80 \%$ & $\begin{array}{l}54.40 \\
(1.13)\end{array}$ & $\begin{array}{l}59.04 \\
(1.01)\end{array}$ & $\begin{array}{c}0.72 \\
(0.06)\end{array}$ & $\begin{array}{c}0.11 \\
(0.01)\end{array}$ & 0.15 \\
\hline
\end{tabular}

Source: PSF survey, authors' simulated distributions, 100 replications, standard errors between parentheses. 